\title{
Urbanismo y territorio en la Antigüedad tardía en Hispania
}

MARÍA-JOSÉ BRAVO-BOSCH${ }^{1}$

\section{RESUMEN}

Este trabajo analiza la realidad de las ciudades de la Antigüedad tardía en Hispania, así como la proliferación de las villae, fenómeno relacionado entre otros motivos con la presión fiscal impuesta a los ciudadanos de la época. En una visión multidisciplinar, se contextualiza la regulación de la vida en los núcleos urbanos y rurales hispanos, sometida a numerosas transformaciones, pausadas en el tiempo, tanto desde el punto de vista histórico como arqueológico, sociológico, religioso y jurídico, a la vez que se evidencia la presencia militar, desorganizada e incapaz de resolver los problemas en las fronteras. Además, se incluyen como conclusiones finales las reflexiones necesarias sobre este momento histórico tan interesante como denostado tradicionalmente.

Palabras clave: Civitas, Villae, Cristianismo, Presencia militar, Fiscalidad.

\section{Urban Planning and Territory in Hispania Late Antiquity}

\section{ABSTRACT}

In this paper we analyze the reality of the cities of late antique Hispania, as well as the proliferation of the villae, a phenomena, which among others, is related to the tax burden imposed on citizens of the time. Using a multidisciplinary

1 Doctora en Derecho y profesora de Derecho Romano, Universidad de Vigo, Vigo, España. Correo-e: bravobosch@uvigo.es Fecha de recepción: 25 de julio de 2016. Fecha de modificación: 2 de septiembre de 2016. Fecha de aceptación: 15 de septiembre de 2016. Para citar el artículo: Bravo-Bosch, M.-J. "Urbanismo y territorio en la Antigüedad tardía en Hispania", Revista Digital de Derecho Administrativo, n. ${ }^{\circ} 16$, segundo semestre, Universidad Externado de Colombia, 2016, pp. 145-191. DOI: http://dx.doi.org/10.18601/21452946.n16.09. 
approach, this paper contextualizes the regulation of life in the urban and rural centers of Hispania, which were subject to numerous transformations, frozen in time, both from a historical perspective as well as archaeological, sociological, religious and legal point of view, while also demonstrating how the military was disorganized and unable to resolve problems on the borders. This paper also includes in its conclusions some necessary final reflections on this historic moment.

Keywords: Civitas, villae, Christianity, Military Presence, Taxation.

\section{INTRODUCCIÓN}

El estudio de la realidad urbanística en Hispania en la Antigüedad tardía debe acometerse de forma unitaria tanto en el ámbito urbano como en el rural, a fin de poder conocer de un modo global los asentamientos urbanos y la transformación del paisaje, así como la conformación de la ciudad tardoantigua y las villas romanas ${ }^{2}$. En esa óptica, a continuación se pone en evidencia la vida cotidiana en las ciudades y en el campo, así como la proliferación de grandes residencias rurales a la vez que se despoblaban las ciudades en este período de la historia -con la explicación pertinente de tal motivación-, y la influencia del Cristianismo con sus iglesias en la realidad del entorno; todo ello unido a las normas urbanísticas impuestas en el territorio de Hispania, como le correspondía al ser una provincia romana. La denominada arqueología de gestión ${ }^{3}$, completada con la realidad jurídica, debe ayudar a conseguir el objetivo final de este trabajo, que no es otro que el dar una visión multidisciplinar y veraz sobre las civitas y las villae en Hispania.

Tradicionalmente, además, las investigaciones realizadas en el ámbito urbano hispano se han centrado en las residencias de la élite peninsular, con sus grandes construcciones y mobiliario de lujo, sin tener en cuenta el modelo de casas del sector no privilegiado ${ }^{4}$, lo que ha llevado a un gran desconoci-

2 Vid. al respecto, ANTONIO FERnÁNDEZ De BujÁN, "Le role structurant des villes dans l'experience juridique romaine", RGDR 13, 2009, p. 2 ss. (disponible en: www.iustel.com), destacando en p. 5 la referencia al Código Teodosiano, 15.1.36, donde se recoge la obligación de reciclar los materiales procedentes de la demolición de edificios públicos, "ce qui correspondrait de nos jours à la politique de recyclage et de protection de l'environnement".

3 José María GurT I ESPARRAguera e ISABEl SÁnCHEZ Ramos, "La ciudad cristiana en el Mediterráneo occidental. La comprensión del mundo urbano tardío desde una perspectiva material", Mainake n. ${ }^{\circ}$ 31, 2009, p. 132: "La consolidación de la llamada arqueología de gestión ha servido también para mostrarnos que hubo una significativa transformación del mundo clásico hispánico, pero que ésta es mucho más compleja de lo que entonces se podía esperar".

4 R. MAR y A. Perich, "Casa y ciudad en la Hispania tardoantigua. La evolución de los modelos tipológicos", en La villa restaurata e i nuovi studi sull'edilizia residenziale tardoantica, Atti 
miento del modus vivendi de la mayor parte de la sociedad de la época, ya que la clase privilegiada era evidentemente menor en términos cuantitativos, pero resulta mucho más atractiva para su análisis por cuanto los vestigios encontrados tienen por lo general mucho más valor, tanto desde un punto de vista material como arquitectónico, arqueológico, histórico e incluso, en muchas ocasiones, jurídico.

Por lo que se refiere al ámbito rural, la actividad arqueológica ha sido intensa en los últimos años, pero ciertamente a veces polémica, ya que, con la intención de magnificar los descubrimientos realizados, se ha llegado a presentar el hallazgo de villas romanas de cierta relevancia como si se tratara del de palacios imperiales que no se corresponden con la realidad, con el fin de revalorizar los yacimientos para poder así conseguir apoyo institucional de las diferentes administraciones que puedan sufragar el coste de los proyectos de excavación ${ }^{5}$.

Todos estos tópicos procedentes de la historiografía tradicional son los que se quiere poner en cuestión en el presente trabajo, por lo que, con apoyo en las evidencias arqueológicas y las diferentes fuentes literarias, jurídicas y epigráficas existentes al respecto, se pretende clarificar el status quaestionis y poner un poco de orden en esa época tan convulsa de la historia de Hispania que es la Antigüedad tardía, y por ende, del agónico Imperio romano al que estaba sometida.

\section{LA CIUDAD TARDOANTIGUA}

La estructura urbana de la ciudad tardía y la transformación de la ciudad clásica en la época tardoantigua coinciden en la pervivencia de la trama urbana del periodo anterior pero con variaciones ${ }^{6}$, que podemos estimar muy importantes, las cuales se manifiestan en la progresiva ocupación de la vía pública -atribuible tanto a la iniciativa privada como a la actuación de los poderes públicos ${ }^{7}-$,

del Convegno del CISEM, Bari, 2014, p. 441, en donde se afirma que "adolecemos de un conocimiento bastante parcial" en lo que se refiere a la casas romanas sitas en suelo urbano, ya que las investigaciones se han dirigido preferentemente hacia las construcciones "que presentaban grandes superficies y programas decorativos de alto nivel, pertenecientes sin duda a las élites. Este hecho ha provocado que todavía hoy, las casas de los sectores no privilegiados, aunque numéricamente mayoritarios, sean en gran parte desconocidas tanto a nivel textual como arqueológico".

5 JAVIER ARCE, "La villa romana de Carranque (Toledo, España): identificación y propietario", Gerión 21, n. ${ }^{\circ}$ 2, 2003, p. 17.

6 Como el abandono de los colectores generales que circulaban bajo la red ortogonal de calles, ya a partir del siglo II.

7 Vid. José María GuRT I Esparraguera, "Transformaciones en el tejido de las ciudades hispanas durante la Antigüedad tardía", Zephyrus, 53-54, 2000-2001, p. 446. 
con el estrechamiento de la calzada o la desaparición de algunos tramos de la misma, lo que provocará la distorsión de la clásica red ortogonal de calles ${ }^{8}$ y la aparición de un nuevo orden urbanístico.

Se produce, por lo tanto, la desurbanización del área residencial intramuros, y la ocupación de la calzada, en sintonía con los cambios estructurales que se habían producido en varias ciudades hispánicas ya a partir de la segunda mitad del siglo II, y de modo especial a partir del siglo III $^{9}$, en el que perdieron su importancia llegando a ser incluso abandonadas ${ }^{10}$, para llegar al siglo IV con la ruptura total del modelo urbano altoimperial. El evergetismo municipal ya había disminuido considerablemente ${ }^{11}$, como consecuencia de los diversos cambios ideológicos más que económicos de las élites sociales ${ }^{12}$, y las obras realizadas se deben al aparato imperial, dirigido a la conservación

8 Ibíd., p. 449, en donde afirma que Barcelona, Barcino, "ofrece pues, en su conjunto, una imagen de respeto al sistema ortogonal fundacional durante todo el período de la Antigüedad tardía", a diferencia de la mayoría de ciudades que se transforman en dicha época.

9 Vid. al respecto, Adela Cepas Palanca, "Crisis y continuidad en la Hispania del siglo III", Anejos del Archivo Español de Arqueología, 17, Madrid, 1997, passim, en donde se muestra la continuidad en la historia de varias ciudades, al mismo tiempo que los cambios profundos experimentados a la luz de la decadencia de otras en igual espacio temporal.

10 GEZA AlfÖldy, "El Imperio romano durante los siglos II y III: continuidad y transformaciones", en Tarraco christiana civitas, JOSEP M. MaCías Solé y ANDrue MuÑoz Melgar (eds.), Tarragona, 2013, p. 26: "Un ejemplo muy significativo es Cartago nova, una ciudad tan floreciente en épocas anteriores: aquí, como sabemos gracias a las investigaciones arqueológicas más recientes, el foro llegó a ser una cantera, el teatro y el anfiteatro fueron abandonados y las casas fueron utilizadas como depósitos de basura $;$ y no sólo se despobló la ciudad sino también su territorio".

11 Ya no era comparable con la generosidad de munificentes ciudadanos de la primera época imperial, cuando después de la conquista de Hispania se comenzó el proceso de municipalización, tal y como pone de manifiesto ENRIQUE MELCHOR GIL, "Construcciones cívicas y evergetismo en Hispania romana", Espacio, Tiempo y Forma, Serie II, 6, 1993, pp. 443 ss., en donde analiza "la labor desempeñada por la iniciativa privada (evergetas) en materia de financiación de edificios públicos de carácter cívico".

12 Vid. John BRYAN Ward-PERKINS, "From Republic to Empire: Reflections of the early provincial architecture of roman West", Journal of Roman Studies, 60, 1970, p. 15, en donde afirma que la clase de los libertos ricos desaparece a lo largo del siglo III, por lo que la ciudad deja de percibir los actos beneficiosos de evergetismo de este grupo de ciudadanos que buscaba mejorar su estatus. Ha dicho ENRIQUE MELCHOR GIL, "Consideraciones acerca del origen, motivación y evolución de las conductas evergéticas en Hispania romana", Stvdia bistórica - Historia Antigua, 12, 1994, p. 81: "Los cambios operados en la estructura del imperio y en la mentalidad de sus élites debieron de jugar un papel fundamental en la desaparición de las conductas evergéticas. Los grupos urbanos que no pudieron promocionar en la administración del Estado comenzaron a infravalorar las magistraturas locales y dejaron de estar interesados en la carrera de los honores municipales, especialmente cuando tomaron conciencia de que ésta sólo les reportaba cargas. Si a este panorama se añade la limitación de la autonomía municipal, el resultado lógico debía ser que los notables locales dejaran de interesarse por los asuntos públicos y por cuestiones como el embellecimiento de sus ciudades, prefiriendo ocuparse de sus negocios y de su propio bienestar". 
de los elementos arquitectónicos de prestigio. La legislación protectora sobre los edificios altoimperiales demuestra graves dificultades para conservar su preeminencia en los núcleos urbanos, al tiempo que la iglesia cristiana comienza a convertirse en una alternativa de gran influencia urbana y social ${ }^{13}$.

La reconversión de estructuras públicas en espacios domésticos será la tónica dominante del nuevo urbanismo de la Antigüedad tardía, en relación con el avance del espacio privado en detrimento del público, lo que se percibe claramente en las termas, los circos e incluso en espacios anteriormente considerados sagrados que ahora serán reutilizados sin ninguna consideración a su cometido anterior, como demuestra la documentación arqueológica existente al respecto ${ }^{14}$, salvo alguna excepción, como sucede en el caso de Carthago Nova ${ }^{15}$.

Con todo, y a pesar de que en el "siglo de la crisis", correspondiente al siglo III, varíe el modelo de organización urbana, centrado en la ciudad, para ceder el protagonismo a la organización rural independiente de la urbs, seguirán existiendo núcleos urbanos en Hispania a lo largo de los últimos siglos del Imperio romano ${ }^{16}$, aun cuando la historiografía anterior apostase por una ruina generalizada ${ }^{17}$. De este modo, es posible comprobar que el urbanismo de la Antigüedad tardía se ha considerado siempre como el punto final de

13 Vid. Josep M. MaCías SolÉ, "Tarraco en la Antigüedad tardía: un proceso simultáneo de transformación urbana e ideológica", en Los orígenes del Cristianismo en Valencia y su entorno, Valencia, 2000, p. 263, en donde se afirma en relación con Tarraco: "Las actas del martirio de San Fructuoso nos dan a conocer al primer obispo hispánico y muestran el Cristianismo como una fe arraigada en la sociedad tarraconense. Tarraco fue, como consecuencia directa de su capitalidad administrativa, sede metropolitana y primada de Hispania. Diversos hechos muestran la consolidación del Cristianismo en Tarraco durante el siglo IV", como resultan ser las evidencias epigráficas, numismáticas e iconográficas que evidencian la actividad conciliar de tal comunidad.

14 Vid. Albert Ribera Lacomba y Miguel Roselló Mesquida, "La ciudad de Valencia en época visigoda", en Los orígenes del Cristianismo en Valencia y su entorno, cit., pp. 161-162, en relación con el abandono del circo de Valentia en el siglo V, cuya reocupación se realizará a partir de la mitad del siglo siguiente: "Sobre la arena, abandonada a lo largo del s. V, que se extendía por una zona de $350 \times 60 \mathrm{~m}$, esto es, 2 hectáreas, aparece un gran relleno artificial de nivelación, originado por el vertido rápido de tierras muy oscuras y ricas en materiales arqueológicos, incluidas pequeñas monedas vándalas, que dan una fecha muy clara, centrada a partir de mediados del s. VI, para su formación".

15 Vid. Sebastián Ramallo AsEnsio, "Carthago Spartaria, un núcleo bizantino en Hispania", en Sedes regiae (ann. 400-800), Gisela RlPOll y José MARía GuRT (eds.), Barcelona, 2000, pp. 591 ss., en donde se da cuenta de que tres siglos después del abandono del teatro se le superpone un mercado, mientras seguía siendo espacio público de la ciudad, y hasta el siglo VI no pasará a ser un espacio de uso doméstico. De este modo el teatro, reconvertido en mercado durante el siglo $\mathrm{V}$, será sustituido por un pequeño barrio durante el siglo $\mathrm{VI}$, siendo hasta el momento el único ejemplo en el que no hay una reocupación de un edificio emblemático correspondiente al período clásico de la ciudad para un uso habitacional.

16 JAVIER ARCE, El último siglo de la España Romana, 284-409, Madrid 1982, p. 99.

17 GonZalo Bravo, "Revolución y 'Spätantike': problemas de método en el análisis histórico de la sociedad tardorromana", Zapbyrus 26-27, 1975-1976, pp. 443 ss. 
la decadencia de Roma, y por lo tanto todas sus manifestaciones siempre se han visto como producto de esa decadencia vital, sin apreciar el período de la Antigüedad tardía como lo que es, a saber, un momento de transición necesario entre diferentes edades de la historia, y por ende, del derecho y de la arqueología presentes en la misma.

El saneamiento urbano también sufrirá grandes cambios en este período. Al margen de ejemplos tempranos que tienen que ver más con situaciones traumáticas de reformas urbanas que con el urbanismo tardoantiguo ${ }^{18}$, los cambios en la red de saneamiento serán habituales en este momento, como demuestran los casos de Emerita ${ }^{19}$ o Barcino, en este último caso coincidiendo además con el abandono de la red de alcantarillado propia de la ciudad ${ }^{20}$.

El cambio en la pavimentación urbana ${ }^{21}$, ahora de tierra batida o cascotes, demuestra la falta de necesidad de un pavimento que realice funciones de cubrición ${ }^{22}$, así como el reciclaje de materiales que procederían en su mayor

18 Vid. José María Gurt I Esparraguera, "Transformaciones en el tejido de las ciudades hispanas durante la Antigüedad tardía", cit., p. 449, en donde se trae a colación el caso de Baetulo, "donde los colectores urbanos quedan inutilizados a partir del siglo II".

19 Miguel Alba Calzado, "Intervención arqueológica en el solar de la c/ Suárez Somonte, esquina con c/ Sáenz de Buruaga. Transición de un espacio doméstico y viario de época romana a la Tardoantigüedad", en Mérida, excavaciones arqueológicas 1998. Memoria 4, Mérida, 2000, p. 291.

20 Julian Beltrán De Heredia Bercero, "Continuïtat i canvi en la topografía urbana. Els testimonis arqueológics del quadrant nord-est de la ciutat", en Julian BELTRÁN De HEREDIA BERCERO (dir.), De Barcino a Barcinona (segles I-VIL). Les restes arqueològiques de la plaça del Rei de Barcelona, Barcelona, 2001, p. 102, en donde se incluye el testimonio de pozos ciegos en la ciudad.

21 JoSEP M. MACías SolÉ, "Tarraco en la Antigüedad tardía: un proceso simultáneo de transformación urbana e ideológica", en Los orígenes del Cristianismo en Valencia y su entorno, cit., p. 262: "La valoración arquitectónica de estos nuevos espacios urbanos define un retroceso general en la calidad técnica y de vida de las nuevas estructuras de hábitat. Durante la Antigüedad tardía se constata en la arquitectura privada el desuso progresivo del mortero de cal, de las cubiertas de tejas cerámicas y el predominio de muros de material lapídeo reciclado unido con arcilla. Asimismo, predominan los pavimentos de tierra batida y destaca la ausencia de un sistema de alcantarillado".

22 José María Gurt I Esparraguera, "Transformaciones en el tejido de las ciudades hispanas durante la Antigüedad tardía", cit., p. 465: "Finalmente, se observa la progresiva desaparición de los elementos de cubrición típicos de épocas anteriores, tegulae e imbrices. No ocurre lo mismo si nos referimos a la arquitectura eclesial. Es muy interesante ver cómo la arquitectura cristiana usa estos elementos y cómo los obispos marcan las partidas de material, ya sean fabricadas en sus propias figlinae o en talleres donde trabajan para la obra pública, lo que indica que la tradición no se ha perdido, sino que lo que ocurre es que se acentúan cada vez más las diferencias entre las técnicas usadas por la obra popular y la obra pública. Sin embargo, es evidente que existe una reutilización en la obra popular tanto de tegulae como de imbrices procedentes de edificios anteriores, aunque también se observan otros tipos de cubrición como ocurre en el barrio portuario de Carthago Nova". 
parte de edificios ahora abandonados pero utilizados con anterioridad como sede de estructuras públicas.

Por otro lado, también se detecta la creación de basureros urbanos, intramuros, en los nuevos barrios creados a partir de la reutilización y ocupación de antiguos edificios públicos en desuso ${ }^{23}$, lo que da cuenta del paisaje particular creado a partir de la unión de viviendas con estos recintos en los que se queman los residuos orgánicos de la población ${ }^{24}$. Los distintos trabajos arqueológicos muestran diferentes tipos de vertidos ${ }^{25}$, y así, mientras unos son fosas excavadas, otros se limitan a ser deposiciones externas que constituyen otra categoría de basureros urbanos, con mayores dimensiones y desarrollo horizontal, que son propiamente vertederos ${ }^{26}$; pero la conclusión en todo caso es la falta de ubicación precisa y delimitada de la deposición de vertidos y la ordenación de los mismos, algo propio de la organización romana en la plenitud de su Imperio ${ }^{27}$, que ahora no se produce de la misma manera.

23 Xavier Dupré Raventós y Josep-Anton Remolà Vallverdú, "A propósito de la gestión de los residuos urbanos en Hispania", en Romula 1, 2002, pp. 52-53: "Entre los depósitos arqueológicos que conforman este nuevo escenario urbano, destacan los vertederos por su vinculación directa con el consumo y el entorno urbano. Especialmente sorprendente es su presencia en espacios públicos en desuso (plazas públicas, edificios lúdicos, calles, etc.) por el contraste que se produce entre la ruinosa monumentalidad de algunos de estos recintos y el proceso de transformación funcional sugerido por la presencia de las áreas de vertido".

24 Existen numerosos ejemplos al respecto a lo largo de la geografía hispana, lo que demuestra su uniformidad en la nueva conformación urbana de las ciudades tardoantiguas.

25 Vid. al respecto, JAIME VizCAínO SÁNCHEZ, "Transformaciones del urbanismo tardoantiguo en Cartagena. El caso de los vertederos", AnMurcia 15, 1999, p. 91, en donde se describe la ubicación de los vertederos tardoantiguos incluso en desniveles: "También otros vertederos tardoantiguos documentados en el Sureste se sitúan igualmente en desniveles, como es el caso de los localizados en las laderas Norte y Sur del Cerro del Castillo de Lorca, o el de Calle San Vicente de Mazarrón. La utilización de pendientes para el vertido de residuos es una constante incluso hoy día, pretendiendo con ello no obstaculizar un hábitat por lo general concentrado en las partes más altas de los cerros, así como facilitar la eliminación de residuos a través del rodamiento".

26 Elena Ruiz Valderas, Sebastián Ramallo Asensio, María Dolores laiz Reverte y María del Carmen BerRocal Caparrós. "Transformaciones urbanísticas de Carthago Nova (siglos III-XIII)", IV Congreso de Arqueología Medieval Española, vol. II, 1993, p. 61.

27 Vid., sobre la ordenación medioambiental en el mundo romano, MARÍA JosÉ BraVO BOSCH, "La protección del medio ambiente en la antigua Roma", Index, 42, Nápoles, Jovene editore, 2014, pp. 491-514, pudiendo destacar la regulación de la actividad de las fullonicae, establecimientos especializados en dos actividades: la primera de ellas consistía en limpiar, lavar y teñir las túnicas utilizadas por los ciudadanos, la segunda, en encargarse de la elaboración, teñido y desengrasado de la lana esquilada y otras materias primas. Como se aprecia en p. 504: "La necesidad evidente de obtener la suficiente orina para llevar a cabo las labores de limpieza llevó a los fullones a colocar en las calles grandes ollas de barro a modo de urinarios, concluyendo su trabajo con el compactado de los paños con bates de madera (abatanado), enjuagando las prendas en piletas (lacunae fullonica) con el claro objetivo de expulsar los detergentes utilizados, para a continuación exponer los vestidos 
La densificación de la población está en relación con la aparición de estos basureros, que hablan de una concentración mayor de población en los núcleos urbanos como característica esencial de la ciudad tardoantigua, que no era propia de la clásica, y que será a la vez causa y efecto de la desertización del territorio ${ }^{28}$.

Todo ello se debe poner en relación con la transformación de la propia sociedad tardoantigua. El motivo del abandono de los edificios públicos paganos tiene que ver con la nueva simbología y el poder creciente del Cristianismo en territorio hispano. Bien es cierto que se procede a la reutilización de elementos de edificios romanos precedentes para la construcción de edificios de carácter cristiano, y por lo tanto se transforman construcciones romanas dotadas de un equilibrio estético que se debería respetar; pero también se ha de convenir en que todas las evidencias de cambios urbanísticos deben ser interpretadas en su justa medida, no como un síntoma de decadencia de la

al humo de azufre quemado, colocándolos sobre una armadura de mimbre. El último paso consistía en aplicar la fullonicatoria (rizoma de un tipo de lirio) como almidón, doblando a continuación los paños y vertiendo sobre ellos una mínima cantidad de agua antes de su prensado. Para poder llevar este trabajo a cabo, al margen de necesitar mucho espacio, y de utilizar el vertedero del vial público, denominado intervallum, debían utilizar cantidades ingentes de agua. Por eso las lavanderías y tintorerías se ubicaban por lo general en la proximidad de cursos de agua, que resultaban por lo tanto contaminados. Tal fue el impacto ambiental que Marcial nos informa sobre una disposición dirigida a tutelar la salud pública, de forma que las tintorerías y lavanderías fueron transferidas más allá del río Tíber, creando una especie de periferia industrial, con todas las actividades industriales contaminantes. Por otro lado, ya en el siglo III a.C., sobre el año 220 a.C., como parece deducirse del testimonio de Plinio, sabemos de la existencia de una ley dirigida a regular la actividad de los fullones, según la información contenida en Nat. bist. 35.57.197: "Proprietas saxi quod crescit in macerando, itaque pondere emitur, illa mensura. Umbrica non nisi poliendis vestibus adsumitur. neque enim pigebit banc quoque partem adtingere, cum lex Metilia extet fullonibus dicta, quam C. Flaminius L. Aemilius censores dedere ad populum ferendam". La lex Metilia fullonibus dicta había prohibido a los tintoreros y los que se dedicaban al negocio de las lavanderías el echar el agua procedente de sus actividades en lugares públicos o en los campos, imponiendo sanciones en caso de contravención de lo dispuesto. Era sin duda un buen proyecto legislativo, aunque la verdad es que la ley no fue casi observada. Como era de esperar, será un remedio pretorio el que ponga freno a las actividades de los fullones, pendientes solo de su enriquecimiento personal y en absoluto preocupados por el medio ambiente. La actio aquae pluviae arcendae, acción personal y arbitraria concedida al propietario de un fundo para solicitar del propietario del fundo colindante la demolición de las obras realizadas en dicho fundo y que han alterado en perjuicio del fundo dominante el curso normal de las aguas, implicaba no sólo la imposibilidad, en el futuro, de realizar la actividad contaminante, sino también la obligación de resarcir por los daños ya ocasionados, de indemnizar por los gastos efectuados para reponer los lugares a su estado original.

28 José María Gurt Esparraguera, "Structuration du territoire dans le nord-est de l'Hispanie pendant l'Antiquité tardive: transformation du paysage et dynamique du peuplement", en Les campagnes de la Gaule à la fin de l'Antiquité. IV Colloque de l'association AGER (Montpellier 1998), Pierre Ouzoulias, Ch. Pellecuer, C. L Raynaud, Paul Van Ossel y P. Garmy (dirs.), Antibes, 2001, pp. 303 ss. 
vida urbana sino como la adecuación a una nueva realidad, producto de los cambios operados de forma gradual con respecto al urbanismo anterior, que no se debe denostar sin más, ya que la destrucción de algunos elementos arquitectónicos trajo consigo la construcción y la puesta en escena de otros, sin duda de igual función y estilísticamente de factura similar a los anteriores ${ }^{29}$.

La creciente influencia del Cristianismo irá mostrando una nueva topografía profundamente cristianizada a partir del siglo $\mathrm{V}^{30}$, con la configuración de una arquitectura episcopal que poco a poco dejará atrás los esquemas de la ciudad altoimperial para concentrarse en la edificación de tipo religioso, la cual asumirá un protagonismo cada vez mayor ${ }^{31}$, hasta desterrar los principios romanos antes respetados en lo que se refiere a la conformación urbanística de las ciudades. Bien es cierto que el escenario presentado de un modo ge-

29 Vid. MANEl FeIJOÓ, "Imbricación de las elites laicas y eclesiásticas durante las transformaciones de la Antigüedad tardía", Antesteria, 2, 2013, p. 167, en donde se hace referencia a las construcciones de carácter cristiano en el interior de la ciudad de Tarraco, en donde se evidencian "actuaciones de época tardoantigua que habían provocado el desmantelamiento parcial del muro de sillares del recinto de culto altoimperial". Y, en p. 168, con respecto a la ciudad de Barcino: "En cuanto al tema de la cristianización de la topografía urbana de Barcino, las intervenciones arqueológicas practicadas durante los últimos años en el subsuelo del actual Museu d'Història de la Ciutat, han permitido documentar la evolución de su conjunto episcopal, que tendrá su origen como en otros casos documentados en Europa en la probable cesión a la comunidad cristiana de una residencia aristocrática".

30 Francisco Salvador Ventura, "La función religiosa de las ciudades meridionales de la Hispania Tardoantigua", Florentia Iliberritana 7, 1996, p. 341: "Durante la Antigüedad Tardía tiene lugar un proceso de redefinición de las funciones de las ciudades en Occidente, adecuándose a las nuevas circunstancias de la época. Entre ellas adquiere una gran relevancia el cometido religioso, sobre todo en las que eran sedes episcopales. Para cumplir con esas funciones las ciudades se transformaron físicamente en el proceso que se ha llamado de cristianización de la topografía urbana. Se trata de un hecho común a todo Occidente, pero tuvo una incidencia especial en las zonas en las que la pervivencia del modo de vida urbano era más significativa, cual es el caso de la zona meridional de Hispania. Entre los edificios religiosos que lo testimonian se encuentran la catedral, presente en todas las sedes episcopales; otros edificios relacionados con ésta; numerosas basílicas, tanto en el interior de la muralla como extramuros; y los monasterios u otro tipo de dependencias monásticas. Para conocerlo en profundidad se dispone aún de escasos datos, proporcionados por las fuentes literarias y la epigrafía. La posibilidad de conseguirlo se encuentra en manos de la arqueología, que, con el resultado de las investigaciones en curso y de las que se desarrollen en el futuro, sin duda contribuirá de forma decisiva a explicar los múltiples interrogantes que sobre este tema todavía existen".

31 MANEL FeIJOÓ, "Imbricación de las élites laicas y eclesiásticas durante las transformaciones de la Antigüedad tardía", cit., p. 170: "El papel de la Iglesia como institución, durante los primeros siglos de la Antigüedad Tardía tal vez no sea tan destacado como en ocasiones se ha pensado, aunque bien es cierto que su importancia e influencia no dejará de aumentar con el tiempo. Desde el punto de vista arquitectónico, el poder en aumento del obispo se manifiesta, para el caso de la península ibérica, en el desarrollo y monumentalización de los grupos episcopales, que impondrán de manera firme su presencia en el interior de las ciudades, tras una lenta y tímida penetración desde sus primeras apariciones en los espacios extramuros de esas mismas ciudades". 
neral no se visualizó de la misma forma en toda Hispania ${ }^{32}$, y menos aún en el noroeste, con una romanización clara pero de características peculiares con respecto al resto de la Península, y que además resulta heterogénea en su conformación eclesial, sin que podamos aceptar que la realidad indígena sea superior al influjo romano y religioso posterior ${ }^{33}$.

Por otro lado, y siempre en relación con el creciente influjo del Cristianismo en nuestro territorio, debemos poner como ejemplo el enterramiento ${ }^{34}$, que ya desde la ley de las XII Tablas estaba prohibido realizarlo -así como la incineración- en el interior de la ciudad ${ }^{35}$, como previene la tabla X. 1: "Hominem mortuum... in urbe ne sepelito neve urito"36.

32 Rosa Sanz SerRano, "Aristocracias paganas en Hispania Tardía (s. V-VII)", Gerión, vol. extra, 2007, p. 451: "En definitiva, debemos rechazar los intentos de presentar los siglos IV y V como un mundo ideológicamente homogéneo, cuya complejidad nos obliga a reflexionar sobre la situación en los márgenes occidentales y en las provincias hispanas. Mi dedicación en otros trabajos al problema de la desaparición del paganismo en ellas me lleva a plantear en este lugar un aspecto no desarrollado suficientemente en ellos: la probable existencia de aristocracias y grupos de poder impermeables al cambio religioso; fenómeno que se incardina con el paganismo de grupos marginales como la bagauda -cuya complejidad desborda este trabajo-, y la existencia de las masas incultas y miserables de las ciudades y el campo a las que los textos antipaganos quieren dar protagonismo exclusivo".

33 José Carlos SÁnChez PARdo, "Organización eclesiástica y social en la Galicia tardoantigua. Una perspectiva geográfico-arqueológica del parroquial suevo", Hispania Sacra 66, 134, 2014, p. 474: "En ese sentido, se observa cómo la primera organización eclesiástica extraurbana en Galicia se basó en las circunscripciones territoriales romanas y tardorromanas. Esto no implica que esta administración perviviese sin cambios, ya que se aprecian ciertas adaptaciones y transformaciones en las jerarquías. Pero desde luego se trata de una base que existía y funcionaba, y que no había sucumbido al final del Imperio romano, como a menudo se sostiene. En este sentido, no podemos seguir manteniendo la tradicional idea de que el Parroquial Suevo refleja una 'estructura indígena' ni mucho menos una continuidad de formas de organización prerromana. A finales del siglo $\mathrm{VI}$, los nombres que cita el Parroquial, al margen de su etimología fosilizada, son simples circunscripciones administrativas tardorromanas. De hecho, la habitual idea de la falta de núcleos o aglomerados centrales en muchos de estos 'territorios indígenas' es discutible. En muchos casos sí existen, aunque han sido obviados o muy poco estudiados todavía por una arqueología clásica demasiado preocupada en poner límites y cesuras a partir del siglo V. En el resto de los casos, esta ausencia de un centro no debe considerarse más que un reflejo de una estructura de poblamiento disperso, sin implicaciones de mayor arcaísmo ni pobreza".

34 Vid. al respecto, Jocelyn M. C. TOYNBEe, Death and Burial in the Roman World, Londres, 1971, passim, en donde se explican los diferentes tipos de enterramientos posibles en el mundo romano, la posibilidad de la inhumación, embalsamiento o cremación de cadáveres, así como la diferente decoración presente en la arquitectura funeraria, evidentemente más rica en la capital del Imperio romano que en sede provincial. Además, se declara en p. 39: "Three types of burial were known in the Late Republic: cremation, embalmment, and inbumation".

35 Incluso fuera de la urbe, la ley de las XII Tablas dicta normas con respecto a la posible ubicación, con la prohibición de situar la pira funeraria cerca de sesenta pasos de un aedes aliena, cuando su dueño no esté de acuerdo: "Rogum bustumve novum vetat propius sexaginta pedes adigi aedes alienas invito domino".

36 Prohibición confirmada posteriormente por una disposición senatorial del año 260 a.C. 
Sin embargo, cuando las construcciones cristianas acceden al núcleo urbano, habitualmente en forma de iglesias, realizan un despliegue monumental en la arquitectura funeraria, y dichas iglesias van acompañadas de lugares destinados a la sepultura y la inhumación ${ }^{37}$, antes totalmente prohibidos en el pomerium ${ }^{38}$, como límite de los confines de la civitas, siendo la práctica funeraria propia de la civilización romana la incineración.

Al cambiar la concepción funeraria se produjeron enterramientos dentro de la urbe ${ }^{39}$, y el concepto de pomerium tuvo que adaptarse hasta su total decadencia como límite para los enterramientos ubicados fuera de la ciudad ${ }^{40}$,

que se mantuvo hasta finales del Imperio; vid. en este sentido, Cic. deleg. 2.23 .58 y 2.24.61, que apoya esta actuación como necesaria para evitar incendios.

37 Vid. Albert Ribera I Lacomba, "La topografía de los cementerios romanos de Valentia", Saitabi 46, 1996, p. 91, en donde se afirma: "Si prestamos atención a los ritos funerarios, globalmente se observa, ya desde fines del siglo II, inicios del siglo III, un predominio casi total de la inhumación", asistiendo al cambio de la incineración por la inhumación, "[q] ue se consolida como exclusiva en el siglo III d.C.".

38 ANTONELLA SimONELLI, "Considerazioni sull'origine, la natura e l'evoluzione del pomerium", Aevum 75, 1, 2001, p. 119: "Il pomerium, non coincidente con il sulcus primigenius, era una linea di confine che delimitava il territorio dell'urbs da quello esterno ad essa fino dall'età regia [... L'ampliamento del pomerium (ius proferendi pomerii) era collegato con l'allargamento dello spazio civico urbano e con l'incremento del territorio conquistato".

39 José María Gurt Esparraguera y Josep M. Macías Solé, "La ciudad y el territorium de Tarraco: el mundo funerario", en Espacios y usos funerarios en el occidente romano, Córdoba, 2002, p. 96: "La presencia de sepulturas intra muros a partir de la Antigüedad tardía es un fenómeno conocido en numerosos núcleos urbanos del Imperio romano y en el caso de Tarraco no es una excepción, pero se trata de un hecho minoritario y sin referencias estratigráficas concretas. La existencia de enterramientos dentro de los límites de la ciudad no implicará que los sectores urbanos donde aparezcan pierdan su función de hábitat sino que parece claro que a partir de ahora se establece una armónica convivencia entre el mundo de los vivos y el de los muertos".

40 Vid. Manuel Dionisio Ruiz BuEnO, "La ruptura funeraria del pomerium desde su nacimiento y hasta su desaparición. Enterramientos in urbe", Onoba, 1, 2013, pp. 187 ss., en donde se habla de la pérdida del significado original de pomerium, así como de la aparición de enterramientos in urbe, afirmándose en p. 198: "Ya en los siglos IV y V d.C., se detecta -junto a otras transformaciones topográficas propias de la ciudad tardoantigua- una clara ruptura funeraria del pomerio en muchas ciudades de la Península Ibérica, lo que atestigua el fracaso de la citada legislación. Esta cronología (cuarta y quinta centuria) contrasta con las de otras ciudades hispanas y, sobre todo, con las procedentes de otras regiones europeas como la Italia Annonaria, donde debemos avanzar a los siglos VI-VII d.C. Entre las posibles explicaciones de este amplio marco cronológico podríamos interpretar la citada ruptura del pomerium como síntoma evidente de una 'crisis' urbana iniciada en tiempos y modos diferentes -una hipótesis a la que parecen apuntar yacimientos como Cartbago Nova o $\mathrm{Mu}$ nigua-; no obstante, en ocasiones la realidad es más compleja y no siempre se conjugan ambos agentes, como en Emporiae o Barcino. Tampoco el nivel de importancia de la civitas es un criterio fiable, al identificarse enterramientos in urbe en la cuarta o quinta centuria tanto en centros episcopales y políticos (Lucus Augusti o Corduba), como en otros con un papel más secundario (Clunia, Veleia o Rbode)". 
anteriormente protegidos, en los que se condenaba la violación de los sepulcros por medio de una acción popular otorgada por la legislación penal romana, la actio de sepulcbro violato ${ }^{41}$, y contenida en Digesto, 47, título XII: De sepulcro violato, sobre la que pesa la infamia, como nos transmite Ulpiano en D. 47.12.1 (ad ed. Praet.): "Sepulcri violatit actio infamiam irrogat".

Se condenaba de forma específica el enterramiento realizado en una ciudad, como dice Ulpiano en D. 47.12.3.5 (ad ed. Praet.):

Divus Hadrianus Rescripto poenam statuit quadraginta aureorum in eos, qui in civitate sepeliunt, quam fisco inferri iussit, et in magistratus eadem, qui passi sunt, et locum publicari iussit, et corpus transferri. Quid tamen, si lex municipalis permittat in civitate sepeliri? Post rescripta Principalia an ab boc discessum sit, vedebimus, quia generalia sunt Rescripta, et oportet imperialia statuta suam vim obtinere, et in omni loco valere.

De este modo Ulpiano nos transmite como el emperador Adriano estableció por rescripto una pena pecuniaria que se debía de pagar al Fisco, contra los que enterraban en una ciudad ${ }^{43}$, siendo condenados con la misma cantidad los magistrados que lo hubieran consentido, disponiendo que el lugar fuera confiscado y el cadáver trasladado. El problema surge cuando la ley municipal permitía el enterramiento en la ciudad, resolviéndolo en el sentido de que los

41 Resulta interesante la opinión de A. SACCOCCIO, "Il modello delle azioni popolari romane tra diritti diffusi e 'class actions'", en 'Actio in rem' e actio in personam'. In ricordo di Mario Talamanca, L. Garofalo (ed.), vol. I, Padua, 2011, p. 747, por lo que respecta a esta acción popular: "La verità è che non si tratta né di interessi privati, tutelabili con vindicationes o condictiones o altro, né di interessi pubblici, che riguardano la collettività come tale, che reagisce ad offese tali, da non poterle tollerare se non a costo di vedere compromesse le ragioni stesse della sua unità. Con le azioni popolari si offre invece tutela ad interessi posti 'dall'ambiente comune in cui si svolgono le attività individuali e quotidiane', che solo adottando una contrapposizione manichea, propria del diritto moderno post-borghese e post-individualista, finiscono per isterilirsi nella contrapposizione pubblico-privato. Essi, in realtà, non sono in senso stretto né pubblici né privati: non sono pubblici, perché la reazione è affidata comunque ai singoli, non sono privati, perché in ogni caso il privato non viene in considerazione uti singulus, ma come parte del populus Romanus, o di una più limitata o diversa collettività (ad es. una civitas), come dimostra anche il fatto che l'azione popolare non entra nel patrimonio del potenziale attore per via di successione ereditaria".

42 Con respecto al sujeto activo de la acción de sepulcro violado nos dice Juliano en D. 47.12.6 (libro X. Digestorum): "Sepulchri violati actio in primis datur ei, ad quem res pertinet. quo cessante si alius egerit, quamvis rei publicae causae afuerit dominus, non debebit ex integro adversus eum, qui Litis aestimationem sustulerit, dari. nec potest videri deterior fieri condicio eius, qui rei publicae causa afuit, cum baec actio non ad rem familiarem eiusdem, magis ad ultionem pertineat", afirmando que la acción le corresponde en primer lugar al sujeto al que pertenece la cosa, y a falta de este, si otro la hubiera ejercitado, aunque el dueño hubiera estado ausente por causa de la República, no se le deberá dar de nuevo contra el que hubiera pagado la estimación del litigio.

43 Distinto es el caso de quien hubiese habitado en un sepulcro, o tuviese en el edificio, dándose la facultad de ejercitar la acción al que quiera, como dice Ulpiano en D. 47.12.3.6: "Si quis in sepulcro babitasset, aedificiumve babuisset, ei, qui velit, agendi potestas fit". 
rescriptos imperiales tienen fuerza de ley general, por lo que deben ser válidos en todo lugar, y por lo tanto prevalentes ante la legislación municipal.

A mayor abundamiento, los suburbia de las ciudades se someten poco a poco a la topografía cristiana ${ }^{44}$, proliferando los espacios funerarios ${ }^{45}$. El urbanismo tardoantiguo desarrollado en el suburbio, urbanismo que supone la desurbanización del área intramuros y el enriquecimiento del área perimetral antes denostada ${ }^{46}$, desaparece gradualmente, lo que se traduce en el abandono de viviendas en los suburbia que no estén relacionados con espacios de culto ${ }^{47}$, articulados con importantes conjuntos martiriales y necrópolis ad sanctos, como manifestación de una arquitectura de poder proyectada para la Iglesia, de acuerdo con la información arqueológica suministrada por las ciudades que tienen espacios periféricos conocidos, al margen de alguna excepción ${ }^{48}$.

De este modo, cabe comprobar que la ciudad tardoantigua se caracterizará por un urbanismo discontinuo y una concentración urbana que gira alrededor de los nuevos centros religiosos intra y extramuros, como manifestación de la

44 Vid. sobre los espacios cristianos en las ciudades hispanas y los enterramientos intramuros, ISABEL SÁNCHEZ RAMOS, Topografía cristiana de las ciudades bispanas durante la Antigüedad tardía, BAR International Series, Oxford 2014, pp. 24 ss.

45 José María Gurt Esparraguera e Isabel Sánchez Ramos, "La ciudad cristiana en el Mediterráneo occidental. La comprensión del mundo urbano tardío desde una perspectiva material", cit., p. 134: "Debido a la reciente expansión urbanística de nuestras ciudades, se han excavado en extensión grandes áreas funerarias localizadas al exterior de los antiguos núcleos urbanos. Por lo que concierne a los cambios que afectan al suburbio, son numerosos los estudios que reiteran el protagonismo y la capacidad de atracción que tuvieron los espacios destinados a necrópolis para el establecimiento de los nuevos conjuntos monumentales. De todos ellos se concluye que tanto el cambio de función de los espacios como la aparición de una nueva arquitectura relacionada con la progresiva implantación del Cristianismo, son los aspectos que con mayor determinación generaron una topografía dinámica, cambiante y finalmente distinta".

46 Josep M. MaCíAS SOlÉ, "Los suburbia en el Mediterráneo de la Hispania Citerior, o los termómetros de la salud del Imperio", en El paisatge periurbà a la Mediterránea occidental durant la protobistòriai l'antiguitat, Institut Català d'Arqueologia Clàssica, Tarragona, 2012, p. 69: "Lo cierto es que la Tarraco portuaria que se define a partir del siglo IV representa un nuevo espacio suburbial donde los recintos residenciales ocupan las antiguas estructuras portuarias altoimperiales y los presuntos recintos de almacenaje disminuyen en extensión y solidez arquitectónica. A la vez se produce la aparición de reducidos complejos termales e, incluso, mausoleos funerarios insertados en una irregular retícula suburbana".

47 Gilberto SÁnchez SÁnchez y Raquel Nodar BeCerRa, "Reflexiones sobre las casas suburbanas en Augusta Emérita", en Mérida, excavaciones arqueológicas 1997. Memoria 3, Mérida, 1999, pp. 371 ss., en relación con la Casa del Anfiteatro de Emerita, abandonada antes del siglo IV, en la que se presenta una necrópolis donde antes se situaban las estructuras domésticas.

48 JosÉ MARÍA GURT I ESPARRAGUERA, "Transformaciones en el tejido de las ciudades hispanas durante la Antigüedad tardía", cit., p. 462: "Lógicamente existen excepciones, en el caso de Emerita la identificación de unas termas fechadas en el siglo VII a unos $500 \mathrm{~m}$ al NE del circo sería una de ellas". 
nueva ciudad policéntrica articulada de acuerdo con la topografía cristiana de la civitas $^{49}$.

\section{LAS VILLAS ROMANAS EN LA ANTIGÜEDAD TARDÍA}

El estudio de las villas romanas de la Antigüedad tardía no está exento de dificultades, ya que las distintas fuentes son escasas y las evidencias presentes en el campo arqueológico demuestran que queda mucho por hacer, dada la parcialidad de los resultados obtenidos en muchas de las investigaciones realizadas, constituyendo además otro aspecto importante la estanquidad de las investigaciones realizadas hasta el momento, ya que se han tratado los elementos indígenas y romanos desde órbitas separadas ${ }^{50}$.

A mayor abundamiento, si nos referimos a las diferencias entre los distintos territorios de la Península es posible encontrar grandes diferencias. Así, por ejemplo, en la Gallaecia era escasa la presencia de ciudades, a excepción de los conventus jurídicos del inicio de la dominación romana, lo que pone en valor el medio rural, en donde se desarrolla un tipo de asentamientos que van a destacar sobre todos los demás, pudiendo destacar de entre todos ellos los vici, o aglomerados secundarios ${ }^{51}$, núcleos de población abiertos, que se convierten en centros neurálgicos a nivel local, profundamente romanos, al margen de los castros prerromanos típicos del noroeste peninsular. Un ejemplo de vicus lo constituye nuestra propia ciudad, Vigo, núcleo de población relevante por su importancia socioeconómica desde un punto de vista marítimo-comercial, que tuvo su mayor esplendor en el siglo I d.C., continuando como vicus varios siglos, hasta su desaparición como hábitat durante la etapa visigótica ${ }^{52}$.

49 Vid. José María Gurt I Esparraguera e Isabel SÁnchez Ramos, "Topografía cristiana en Hispania durante los siglos $\mathrm{V}$ y VI", en El tiempo de los bárbaros. Pervivencia y transformación en Galia e Hispania (ss. V-VI d.C.), Alcalá de Henares, 2010, p. 322, en donde se señala: "Este esquema urbano comporta el abandono de los modelos reticulares y su sustitución por un itinerario estacional bipolarizado topográficamente en torno al episcopium martyrium. Los casos hispanos de Tarraco y Emporiae ejemplifican perfectamente la dinámica de los centros policéntricos".

50 ERIK CARLSSON-BRANDT, "El poblamiento rural en la Galicia Romana. Un ejemplo: las villae. Metodología y problemática en su estudio", Estrat Crític 5, 1, 2011, p. 157.

51 Fermín PÉREZ LOSADA, "Hacia una definición de los asentamientos rurales en la Gallaecia: poblados (vici) y casas de campo (villae)", en CARMEN FERNÁNDEZ OCHOA (coord.), Los finisterres atlánticos en la Antigüedad. Época prerromana y romana, Madrid, 1996, pp. 189 ss.

52 Vid. al respecto, Fermín Pérez LosAdA, "Entre a cidade e a aldea", Brigantium 13, 2002, p. 266: "O abandono debeu producirse durante a segunda metade da sexta centuria, sendo prácticamente inexistentes os argumentos que poderían probar unba certa continuidade de bábitat durante a etapa visigótica. Cando Vigo rexurda como pequeño núcleo de poboación rural nos ss. XI-XII d.C., época da que datan as primeiras referencias documentais e artísticas, será prácticamente unba fundación ex novo". 
De acuerdo con estas premisas, el presente trabajo intenta reconstruir la realidad de tales construcciones conocidas como villae, desde su propia definición y realidad jurídica hasta la función de las mismas en un contexto histórico marcado por continuos cambios, llegando incluso a suponer en cierta medida las transformaciones arquitectónicas y funcionales en las villas romanas occidentales en el periodo tardoantiguo (siglos $\mathrm{V}$ a VIII) el origen del poblamiento rural altomedieval ${ }^{53}$.

La villa romana, reconocida, en su ubicación fuera de la urbe, como construcción rural en que la casa y el dominio territorial debían atenderse de igual manera, es distinguida por Plinio, en N. H. 18, 7, 32, cuando declara que ni la finca, fundus, haga de menos a la casa, villa, ni la casa a la finca:

Modus bic probatur, ut neque fundus villam quaerat, neque villa fundum, non, ut fecere iuxta diversis in eadem aetate exemplis L. Lucullus et Q. Scaevola, cum villa Scaevolae fructus non caperet, villam Luculli ager, quo in genere censoria castigatio erat minus arare quam verrere. nec boc sine arte quadam est. novissimus villam in Misenensi posuit C. Marius VII cos., sed peritia castra metandi sic, ut conparatos ei ceteros etiam Sulla Felix caecos fuisse dicere.

Del mismo modo, Florentino la define así en Digesto 50.16.211 (libro 8, Institutionum): "Fundi appellatione omne aedificium et omnis ager continetur, sed in usu urbana aedificia $<$ aedes $>$, rustica $<$ villae $>$ dicuntur. Locus vero sine aedificio in urbe $<$ area $>$, rure autem <ager> appellatur, idemque ager cum aedificio <fundus > dicitur".

Esta descripción resulta de gran utilidad, ya que clarifica el nombre de fundus, con el que se designa a todo edificio y a todo campo, aunque sea costumbre en la ciudad hablar de "aedes", y en el campo de "villae". Por otro lado, se puede ver cómo un terreno sin edificar es area en la ciudad y ager en el campo, así como que el mismo ager con un edificio se llama fundus.

También cabe traer a colación la distinción entre fundus y locus realizada por Ulpiano, en Digesto 50.16.60 (libro 69 ad Edictum), por su relación con la villa:

Locus est non fundus, sed portio aliqua fundi, fundus autem integrum aliquid est, et plerumque sine villa locum accipimus. Ceterum adeo opinio nostra et constitutio locum a fundo separat, ut et modicus locus possit fundus dici, si fundi animo eum babuimus. Non etiam magnitudo locum a fundo separat, sed nostra affectio; et quaelibet portio fundi poterit fundus dici, si iam boc constituerimus.

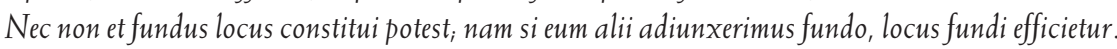

53 José Avelino GutiéRREZ GonZÁLEZ, "Las villae y la génesis del poblamiento medieval", en Carmen Fernández Ochoa y Virginia García-Entero, Fernando Gil Sendino (eds.). Las villae tardorromanas en el occidente del Imperio. Arquitectura y función, Gijón, 2008, pp. 216 ss., resumiendo en p. 234: "el origen y formación del poblamiento y las estructuras socioeconómicas medievales presentan diversas vías genéticas, derivadas tanto de la ruptura como de la transformación de las haciendas romanas". 
Con todo, la villa romana no supone sólo la presencia de una casa en el campo, sino que resulta necesaria la presencia de la productividad del campo como criterio valorativo de la condición de villa, como referente de la organización social y económica del mundo romano ${ }^{54}$. Es cierto que existían grandes villas lujosas pertenecientes a la aristocracia romana, pero la mayor parte, y sobre todo las existentes en territorio hispano, responden a una ambivalente concepción, es decir, es un establecimiento en un fundus, en una finca productiva, y además una casa construida fuera de la ciudad, condicionando el pluralismo del término las características particulares de cada villa y la ubicación geográfica de las mismas ${ }^{55}$.

Además, no por evidente se debe dejar de señalar que en el ámbito rural no eran villae todos los edificios, ya que las fuentes hablan de la existencia de stationes y mansiones, y otras estructuras más sencillas como casae o tuguria, así como núcleos de habitación amplios como los vici, castra o castella.

La evolución del significado de villa se percibe claramente en la literatura tardía ${ }^{56}$, que la describe de modo tópico sin detenerse en lo que se refiere a su transformación o desaparición, pero que sirve para comprender el cambio conceptual de las villae ${ }^{57}$, que ya no son -como en la época altoimperial, donde el pagus es la organización territorial base del sistema donde están los distintos asentamientos que forman el paisaje rural de la época romana, como son también los castella, vici, etc.- unas construcciones con una parte residencial, la pars urbana $a^{58}$, y otra agraria, la pars rustica ${ }^{59}$, sino también, a partir

54 Vid. Albert Grenier, Habitations gauloises et villas latines dans la cité des Médiomatrices, París, 1906, p. 57, en donde se define la villa como "la casa de la granja necesaria para la puesta en valor de la tierra".

55 María Cruz Fernández CAStro, Villas romanas en España, Madrid, 1982, p. 273: "la villa es, pues, la asociación de un doble contenido: el establecimiento (factor económico de producción) y la vivienda en el campo. Si dentro de la correlación de lo rústico (la interdependencia con la hacienda) y lo urbano (casa acomodada al sistema de vida romanizado de la urbe), uno de los dos conceptos fuera arqueológicamente prevalente sobre el otro, éste sería el de la construcción doméstica fuera de la ciudad. Tanto histórica como literariamente, la villa es una edificación en la hacienda, pero, en definitiva, una construcción rural que sirve de vivienda. Este destino de casa y de granja es el que virtualmente define a la gran mayoría de villas".

56 JosÉ IgnaCio MARTíneZ MELÓn, "El vocabulario de los asentamientos rurales (ss. I-IX d.C.): evolución de la terminología", en AleXANDra ChavarRía, Javier ArCE y Gian Prieto Brogliolo (eds.), Villas tardoantiguas en el Mediterráneo occidental, Madrid, 2006, pp. 113-132.

57 JeAN GERARD GORGES, Les villes bispano-romaines. Inventaire et problématique archéologiques, Burdeos, 1979, pp. 11-12

58 Jorge LóPEZ QUiRoga y Germán RodríGUeZ Martín, "El final de las villae en Hispania. I. La transformación de las pars urbana de las villae durante la Antigüedad tardía", Portugalia XXI-XXII, 2000-2001, pp. 137 ss.

59 COLUMELA, 1.6.1, en donde añade la pars fructuaria: "Modus autem membrorumque numerus aptetur universo consaepto et dividatur in tres partes: urbanam, rusticam, fructuariam". 
de mediados del siglo IV, el conjunto de propiedades que dependen de una edificación residencial ${ }^{60}$. Bien es cierto que en el año 380 el segundo de los cánones del Concilio de Zaragoza citan las villas alienae, en referencia a los lugares frecuentados por los priscilianistas, condenando a los seguidores de Prisciliano que se escondían y reunían en esas villae ${ }^{61}$, para hacer el ayuno en los domingos, prohibido por los conciliares:

II. Ut diebus dominicis nullus ieiunet nec diebus quadragesimis ab ecclesia absentet. Item legit:

Ne quis ieiunet die dominica causa temporis aut persuasionis aut superstitionis, aut quadragesimarum die ab ecclesiis non desint, nec babitent latibula cubiculorum ac montium qui in bis suspicionibus perseverant, sed exemplum et praeceptum custodiant et ad alienas villas agendorum conventum causa non conveniant. Ab universis episcopis dictum est: Anathema sit qui boc conmiserit.

Aunque también se pueda apreciar en la legislación visigoda -como la lex $V i$ sigothorum ${ }^{62}$, de finales del siglo VII- que aparece el término villa ${ }^{63}$ : ita ut non sit penitus civitas, castellum, vicus aut villa vel diversiorum, in quibus mancipia latere minime dignoscantur, la realidad es distintas al margen de estos ejemplos, ya que a partir del siglo V empieza a ser sustituida por villula ${ }^{64}$, praetorium o castellum. Estos últimos, los castella, asentamientos aristocráticos de tipo fortificado, aparecen

60 El propio Isidoro, en sus Etymologiae, 15.13, identifica villa no con la edificación residencial sino con todas las propiedades que dependen de ella: "Villa a vallo, id est agere terrae, noncupata, quod pro limite constitui solet". Vid. DiETRICH CLAUDE, "Haus und Hof im Merowingerreich nach den erzählenden und urkundlichen Quellen", en Bericht über zwei Koloquien der Kommission für die Altertumskunde Mittel-und Nordeuropas von 24 bis 26 Mai 1990 und 20 bis 22 November 1991 (34 und 35 Arbeitstagung), Gotinga, 1997, pp. 321-334, donde se analizan de forma minuciosa las fuentes de este periodo.

61 Vid. al respecto, Amancio Isla Frez, "Villa, villula, castellum. Problemas de terminología rural en época visigoda", Arqueología y Territorio Medieval, 8, 2001, p. 10: "Los conciliares parecen haber estado preocupados por el hecho de que algunos cristianos no acudieran a la misa dominical, sobre todo ante la proximidad de la Epifanía. Por ello el canon IV de ese mismo concilio dictamina que no hay que esconderse in domibus, ni recluirse en las villae, ni tampoco dirigirse a los montes [...] Por tanto, en torno al 400 la villa era uno de los ejes de la vida rural de la Hispania de la Tardía Antigüedad. Sin embargo, los usos, al menos los lingüísticos, están cambiando y el término villa inicia un cierto ocaso que no podemos valorar plenamente, dada nuestra escasez de fuentes literarias para el siglo $\mathrm{V}^{\prime \prime}$.

62 IX, 1, 21.

63 AleXandra Chavarría Arnau, El final de las villae en Hispania (Siglos IV-VII d.C.), Turnhout, 2007, p. 153: "En las leyes visigodas raramente aparece el término villa sino que se alude a locus o possessio lo mismo que en las VSPE o en el testamento de Vicente (primera mitad siglo VI) donde se hace referencia a locus, terra, domus, casa o portio pero nunca a villa".

64 Vid. Amancio Isla Frez, Villa, villula, castellum, cit., p. 13, en donde se afirma que aunque se siga utilizando en ocasiones la palabra villa, en realidad desde el siglo VI villula es la forma que se emplea para señalar una "explotación agraria con su centro construido". 
seguramente también en Hispania ${ }^{65}$, aunque todavía poco estudiados, coincidiendo con el nacimiento y desarrollo de aldeas en zonas de la Península Ibérica también a mediados del siglo $\mathrm{V}$.

En apoyo de esta tesis, pero con toda la prudencia interpretativa que merecen las fuentes literarias de la época por su naturaleza retórica y escolástica, cabe traer a colación la Crónica de Hidacio (Chronica 109), en donde utiliza los términos villae y castella: "Hispani per civitates et castella residui a plagis barbarorum per provincias dominantium se subiciunt servituti ${ }^{66}$; Mense Iuno in Gallaecia, coruscatione villae exustae".

En este fragmento se aprecia cómo Hidacio pone de manifiesto dos acepciones distintas, en las que algunos han querido ver una correspondencia entre castella y castrum ${ }^{67}$, algo difícil de aceptar si pensamos que Hidacio no se está refiriendo sólo al territorio galaico, sino a todas las provincias de Hispania ${ }^{68}$.

Del mismo modo, Valerio del Bierzo habla de estos castella bajo la protección de grandes propietarios: "castello cujus vetustus conditor nomen edidit Rufiana"69.

Todas las nuevas realidades territoriales tienen que ver con el abandono de las ciudades cuando estas pierden gran parte de su autonomía, y con el regreso al campo, para vivir en hábitats secundarios, de diferentes nombres -como se viene de ver-, que se adaptan a circunscripciones administrativas con una clara finalidad fiscal, formando parte la villa de la subdivisión administrativa de la civitas, pero constituyendo, desde la perspectiva fiscal, una circunscripción administrativa inferior a la del vicus. La villa responde a una lógica de apropia-

65 Vid. Gian Pietro Brogiolo y Alexandra Chavarría Arnau, "El final de las villas y las transformaciones del territorio rural en Occidente (siglos V-VIII)", en CARMEN FERNÁNDEZ OCHOA, VIRGINIA GARCíA-ENTERO y FERNANDO GIL SENDINO (eds.), Las villae tardorromanas en el occidente del Imperio. Arquitectura y función, Gijón, 2008, p. 196.

66 Hydacio, 41 (The Chronicle of Hydatius and the Consularia Constantinopolitana. Two contemporary accounts of the final years of the Roman Empire, R. W. BURGESS [ed.], Oxford, 1993).

67 Vid. Gerardo Pereira Menaut, "Los castella y las comunidades de Gallaecia", Zephyrus 34 35,1982 , pp. 249 ss., en donde se defiende que los castella surgieron de castros indígenas y que eran por tanto lugares de hábitat continuado.

68 Vid. al respecto, JAVIER ARCE, "Villae en el paisaje rural de Hispania romana durante la Antigüedad tardía", Anejos de AEspA 39, 2006, p. 10, en donde se afirma no creer que los castella sean los castra prerromanos, ya que lo que hace Hidacio es presentar de forma nítida los dos tipos de hábitat existentes en Hispania en su época. JAVIER ARCE, Bárbaros y Romanos en Hispania (440-507 A.D.), Madrid, 2007, p. 236: "El castellum/villa posee, sin duda, rasgos y características propias, y puede ser un emplazamiento en alto o simplemente uno mejor defendido que otros, en el llano, pero menos preparado para la defensa".

69 Valer. Bergid. Ordo 7, p. 169, 5; esta protección ha llevado a parte de la doctrina a identificar castellum con villa fortificada; sin embargo, en RAUL REVUELTA, La ordenación del territorio en Hispania durante la Antigüedad Tardía. Estudio y Selección de Textos, Madrid, 1997, pp. 69 ss., se alude a una unidad de poblamiento mucho más extensa, interpretación avalada por las referencias presentes en la Vita Sancti Aemiliani, donde aparece primero la mención de castro Bilibiensi y más tarde la de Castellum Bilibium. 
ción privada de parte del suelo para la producción y residencia, y en segundo lugar, para la circulación que gestionan los possessores con fines especulativos, de forma que puedan llegar a convertirse en auténticos centros de control y administración fiscal de una circunscripción ${ }^{70}$.

Hay que tener en cuenta que a lo largo del siglo IV la fiscalidad sobre los territorios provinciales periféricos, como es el caso de Hispania, fue una fiscalidad dura, compleja y a menudo modificada, debido a que las luchas internas y externas a las que debía hacer frente el Estado romano, así como la necesidad de mantener relaciones de equilibrio, con frecuencia inestables, con los grupos de bárbaros siempre amenazantes, obligaban a seguir contando con recursos económicos suficientes obtenidos regularmente.

La presión fiscal es denunciada, entre otros, por Salviano de Marsella ${ }^{71}$, que es quien mejor transmite la ineficacia de la administración romana y la tremenda fiscalidad aplicada en Hispania y la Galia, que condujo a que mucha población entrase a depender, como colonos, de los aristócratas locales, que se comprometían a pagar los tributos exigidos por Roma a cambio del control sobre las tierras y servicios, en un intento de asumir cada vez más poder en detrimento del vacío que del mismo iba dejando el Estado romano. Es cierto que estos colonos debían seguir pagando un canon al dominus, pero era este quien asumía ahora el protagonismo en su nombre en las relaciones con la administración ${ }^{72}$. Así, los grupos privilegiados se fueron haciendo con el tiempo con más tierras, poder y privilegios, lo que condujo en no pocas ocasiones a enfrentamientos entre los mismos, pudiéndose incluso entender el conflicto priscilianista como un ejemplo dentro del convulso proceso de posicionamiento de esta nueva aristocracia ${ }^{73}$.

Con todo, las injusticias derivadas de la aplicación de este sistema, con respecto a las tasas aplicadas en Hispania desde mediados del siglo IV, se recogen ya en el Código Teodosiano ${ }^{74}$, en un rescripto dirigido en el año 369 al

70 Jean Durliat, Les finances publiques de Diocletien aux Carolingiens (284-889), Beibefte der Francia, 21, Sigmaringen, 1990, p. 256: "Les villes constituaient des circonscriptions sans doute soumises à une autre fiscalitè encore que les areae situées intra muros payaient sans doute l'impôt foncier de même que les maisons et immeubles, avec ou sans jardin. Les vici, castella ou castra sont des agglomérations intermédiaires, sans doute plus peuplés que les villages environnants, assurément pourvus de fonctions administratives, ce qui les distingue des simples villages mais soumis à la même fiscalitê".

71 De gub. Dei, 4.4.20; 4.6.30; 54.1 ss.; 5.7.12-37; 5.8.34.

72 Vid., sobre el colonato tardío, FRANÇOIS L. GANSHOF, "Le statut personel du colon au Bas-Empire. Observations en marge d'une théorie nouvelle", L'Antiquité classique, 14, 1945 , pp. 261 ss.; ARNOLD Hugh MARTIN JONES, The Later Roman Empire (284-602), Oxford, 1964 pp. 610 ss.; RAMÓN TEJA, "Honestiores y bumiliores en el Bajo Imperio: hacia la configuración de clases sociales de una división jurídica", Mem. de Hist. Ant. 1, 1977, pp. 115 ss.

73 Rosa SANZ, "Aproximación al estudio de los ejércitos privados en Hispania durante la Antigüedad tardía", Gerión 4, 1986, p. 247. 
vicarius Hispaniarum en el que se pide la revisión de los impuestos de la diócesis porque parece que se ha hecho injustamente el baremo de las tasas:

Imppp. Valentinianus, Valens et Gratianus aaa. ad Artemium vicarium Hispaniarum. Quotiens in disceptatione constiterit inique discussionem fuisse confectam et fidem facti non poterit adprobare discussor, ipse in eodem titulo et in eodem modo ad solvendum protinus urgeatur, in quo alterum perperam fecerit debitorem. Dat. prid. id. mai. Valentiniano nb. p. et Victore conss. (369 mai. 14).

También Orosio, en su Hist. adv. pag. ${ }^{75}$, manifiesta: "quamquam et post boc quoque continuo barbari exsecrati gladios suos ad aratra conuersi sunt residuosque Romanos ut socios modo et amicos fouent, ut inueniantur iam inter eos quidam Romani, qui malint inter barbaros pauperem libertatem, quam inter Romanos tributariam sollicitudinem sustinere".

Aquí denuncia la presión fiscal cuando señala que los bárbaros se dedicaron a la agricultura, manteniendo como aliados a los romanos, entre quienes había ciudadanos romanos que eligieron -antes que la preocupación por la tributación excesiva impuesta por Roma- la dependencia de un patrono, que ahora se convertiría en el encargado de enfrentarse con los temidos recaudadores.

De este modo, los nobles locales asumen una nueva posición de control sobre la población, en una relación de dependencia dominus-patronus, en el que se percibe que los colonos, en distintas ocasiones, están ligados a las explotaciones, pudiendo incluso ser vendidos con las tierras desde principios del siglo IV, lo que supone el nacimiento de un sistema de control territorial nuevo. Así, durante el siglo IV las villas hispanas tuvieron un auge sin precedentes ${ }^{76}$, motivado por la decadencia de la vida urbana, supuestamente causada por los desórdenes de la anarquía militar y las invasiones franco-alemanas de mediados del siglo III, siendo totalmente cierto que las ricas aristocracias urbanas se trasladaron al campo, evitando así cargos onerosos en la administración municipal de ciudades en ruinas, y eludiendo con ello la presión insostenible del Fisco.

76 Vid. Dimas FernándeZ-Galiano, "Las villas hispanorromanas", en Cuadernos del Arte español, Madrid, 1998, p. 10, en donde se afirma: "Las clases pudientes habrían abandonado sus antiguas sedes y construido ricas residencias campestres en las que dedicarse a la supervisión de sus producciones agropecuarias y a formas más o menos exquisitas de ocio habrían llevado consigo, a sus nuevas viviendas, todos los refinamientos que la ciudad podía ofrecerles, construyendo termas, piscinas, gimnasios, edificios ricamente ornados con peristilos, grandes salones de recepción, columnatas y un amplio etcétera, que constituye lo que ha dado en llamarse con cierta fortuna en la literatura especializada urbs in rure" $^{\prime \prime}$ añadiéndose en p. 11 que el término urbs in rure es engañoso por cuanto propone que pueda ser una ciudad algo que no lo es, y destacándose en p. 12 que "sería ingenuo pensar que una residencia campestre puede ofrecer las ventajas de la urbe: la vida en ésta significa el foro, la basílica, los monumentos públicos, el mercado, las transacciones, los tribunales de justicia, los espectáculos, la vida pública, el bullicio; el negotium, en suma, por oposición al otium de la vida campestre y retirada". 
A mayor abundamiento, las desigualdades sociales crecientes terminaron por degenerar en un grupo de bandas más o menos organizadas, que realizaban incursiones de pillaje sobre todos dirigidas a las ricas villas existentes, lo que obligaba a que estas contasen con una mínima organización armada para poder hacerles frente, como refleja el Código Teodosiano, 7.1.16:

Idem aa. Theofilo vicario Asiae. Si quos milites per provincias relictis propriis numeris passim vagari cognoveris, correptos facias custodiri, donec de bis clementiae nostrae auribus intimetur et quid fieri oporteat decernamus; ita ut, si quis miles in provincia sine suo numero repertus fuerit ac post elapsus esse nuntiabitur, facultatum suarum, periculo totius officii, condemnatione gravissime vindicetur. Dat. V kal. feb. Constantinopoli Honorio a. III et Eutychiano conss. (398 ian. 28)

\section{También en Código Teodosiano 7.20.7:}

Idem a Evagrio praefecto Urbi. Quosdam veteranos boc nomine indignos latrocinia perpetrare comperimus, ideoque praecipimus, ut veterani, quibus bona mens est, aut arva versent aut certe in optimis negotiis pecuniam tractent et mercimonia agitent. Qui vero neque rus colunt neque utilem vitam commerciis exbibent, mox in ipsos capitaliter exsurgendum. Exui enim omnibus privilegiis debent, per quos publica quies perturbatur, ita ut, si levissimum aliquid deliquerint, omnibus subiciantur poenis. Dat. III id. aug. Constantio a. VI et Constante II conss. (353 [?] aug. 11).

Aquí se puede observar que algunas bandas estaba conformadas por miembros del ejército huidos que actuaban como delincuentes y bandoleros. En Hispania existían todavía en época visigoda, como aseguran Valerio, en Vita Sanct. Fruct. ${ }^{77}$, y la lex Visigothorum ${ }^{78}$, siendo los contingentes sacados de los predios los encargados de su represión.

Un ejemplo muy conocido lo constituyen los personajes de Dídimo y Veriniano ${ }^{79}$, aristócratas hispanos y parientes de Honorio, defensores del control del Imperio sobre Hispania en el año 407 ante la usurpación de Constantino III y los bárbaros con los que había pactado un foedus, aunque seguro que lo hicieron sobre todo para defender sus propios intereses, si bien es cierto que

79 JaVIER ARCE, Bárbaros y Romanos en Hispania, cit., 240: "A comienzos del siglo V hubo, ciertamente, un gran abandono de villae y fundi, fenómeno que está ejemplificado en el episodio de Dídimo y Veriniano y sus parientes Lagodio y Teodosiolo. Dídimo y Veriniano, propietarios de grandes predios en Hispania, fueron capturados con sus familias y decapitados por orden de Constantino III. Teodosiolo y Lagodio huyeron a Rávena y Constantinopla, respectivamente, como consecuencia del triunfo de los leales al usurpador. Ya tenemos aquí un primer abandono de grandes propiedades que quedaron libres para su reocupación por parte de la población local o por los mismos siervos, colonos o gestores de las propiedades cuando estaban sus patrones". 
para hacer frente a esta amenaza olvidaron sus anteriores desavenencias. Sobre este episodio escribe Orosio ${ }^{80}$, en Hist. Adv. pag. 7.40.4-7:

His per Gallias bacchantibus apud Britannias Gratianus, municeps eiusdem insulae, tyrannus creatur et occiditur. buius loco Constantinus ex infima militia propter solam spem nominis sine merito uirtutis eligitur: qui continuo, ut inuasit imperium, in Gallias transiit. ibi saepe a barbaris incertis foederibus inlusus, detrimento magis reipublicae fuit. 5 misit in Hispanias iudices: quos cum prouinciae oboedienter accepissent, duo fratres iunenes nobiles et locupletes Didymus et Verinianus non assumere aduersus tyrannum quidem tyrannidem sed imperatori iusto aduersus tyrannum et barbaros tueri sese patriamque suam moliti sunt. quod ipso gestae rei ordine patuit. 6 nam tyrannidem nemo nisi celeriter maturatam secrete inuadit et publice armat, cuius summa est assumpto diademate ac purpura nideri antequam sciri, bi uero plurimo tempore seruulos tantum suos ex propriis praediis colligentes ac uernaculis alentes sumptibus nec dissimulato proposito absque cuiusquam inquietudine ad Pyrenaei claustra tendebant. 7 aduersus bos Constantinus Constantem filium suum, - pro dolor! - ex monacbo Caesarem factum, cum barbaris quibusdam, qui quondam in foedus recepti atque in militiam allecti Honoriaci uocabantur, in Hispanias misit. binc apud Hispanias prima mali labes.

Estamos ante tropas privadas a pesar de que apoyaban la legitimidad de Honorio, siendo esta una de las principales características de los ejércitos de la Hispania tardoantigua. Además, no tenían nada que ver con la estructura general militar del Imperio ni sus componentes eran soldados al servicio del mismo, ni los cabecillas pertenecían a la administración romana ${ }^{81}$. Como dice Orosio, las tropas las conformaron con siervos de sus predios, y se equiparon con dinero propio para luchar por la legitimidad del Imperio ante la usurpación injusta ${ }^{82}$.

Por lo que respecta a la arquitectura de las villas hispanas, se caracterizan por una personalidad única, tanto por su apogeo tardío con respecto a otras villas pertenecientes al Imperio romano como por la clara influencia del hábitat urbano que va a suponer un fuerte desarrollo de la pars urbana de estas villas, en busca del esquema organizativo perfecto de la residencia ideal ${ }^{83}$. Las élites

80 Historiador hispano controvertido sobre el que JosÉ MARÍA BLÁZQUEZ, "El nombre de Hispania aparece en la historia. Los hispanos en el Imperio Romano", en De Hispania a España, Vicente Palacio AtARd (ed.), Madrid, 2005, afirma en p. 36: "Las Historias de Orosio son una demostración apasionada de que los males del pasado eran más terribles que los del presente. Es una obra apologética. No utiliza directamente los autores que cita. No es erudito ni cuidadoso. Toma sólo de los autores lo que le es útil".

81 Vid. Rosa SanZ, "Aproximación al estudio de los ejércitos privados en Hispania durante la Antigüedad tardía", cit., p. 235.

82 No consideramos como otro motivo el hecho de que estuvieran obligados por pertenecer a un collegium iuvenium, como afirma RAMSAY MACMULLEN, Soldier and Civilian in the Later Roman Empire, Harvard, 1967, pp. 138 ss.

83 Vid. JEAN-GÉRARD GORGES, "L'architecture des villae romaines tardives:la création et le développement du modéle tétrarchique", en Las villae tardorromanas en el occidente del Imperio, cit., p. 30, en donde se describe la villa ideal: "un péristyle avec bassin, avec au nord la salle à 
buscan el confort en sus villas, como lo representan las termas y la calefacción por medio del bypocaustum, y una arquitectura acorde con su estatus, como son las columnas, ábsides, pavimentos de mosaicos, jardines, fuentes, que ilustre sobre la posición dominante del dueño de las mismas. A mayor abundamiento, en el siglo IV la búsqueda de nuevos elementos arquitectónicos para las villas se realiza para confirmar y remarcar la posición económica y social del propietario, lo que se traduce en un cambio de naturaleza de la pars urbana, con la inclusión de salas de recepción, zonas de tránsito, viviendas privadas, en una clara imitación del arte oficial de la Corte Imperial.

Villas como la de Carranque (Toledo), lujosa y ricamente decorada como corresponde a la época en la que el dominus desea presentarse con toda su riqueza y esplendor ${ }^{84}$, o la de la Olmeda (Palencia) ${ }^{85}$, con mosaicos exquisitamente elaborados que pavimentan su suelo y considerada uno de los mayores descubrimientos de la arqueología moderna, propiedad del núcleo aristocrático de la época, y por lo tanto construida con todo tipo de lujos, representan a la perfección los fundi tardorromanos hispanos, a los que podríamos añadir una numerosa relación de asentamientos rurales tipo villa activos en esta época.

A mayor abundamiento, consideramos necesario hacer una mayor referencia -por sus peculiaridades-a la Gallaecia, provincia romana que desde la reforma de Diocleciano comprendía el norte de Portugal y las provincias españolas de Asturias, León, norte de Zamora, hasta el río Duero, y parte de Castilla. Además, cabe decir que desde los primeros momentos de la dominación romana del noroeste la tributación fue un elemento esencial para el posicionamiento de la aristocracia ante el poder romano en el marco de ciudades con el estatus de peregrinas. De hecho, las relaciones de patronato aparecen aquí siempre amplificadas, seguramente por el peso marcadamente rural de estas zonas, con escasa urbanización en toda la Antigüedad, que supone la presencia de patronos con un marcado poder en la política de la Antigüedad tardía, con amplias tramas clientelares.

manger (triclinium) dans l'axe de l'entrée situé au sud, un grand salon (oecus ou exèdre) au milieu $d u$ coté est et la zone thermale occupant de préférence l'angle nord-ouest. Autour de cet ensemble, la pars rustica peut s'agencer de multiple manière. Dans les pays du Nord, en revanche, où le plan linéaire à galeries est assez caractéristique, ce dernier va donner naissance à un plan type d'exploitation à doublé cours, dans laquelle la pars urbana vient le plus souvent fermer la cour intérieure".

84 Aunque esta villa está sometida a una gran polémica en lo que se refiere al posible propietario de la misma. Vid. al respecto, JAVIER ARCE, "La villa romana de Carranque (Toledo, España): identificación y propietario", Gerión, 21, 2, 2003, p. 25: "Empeñarse en buscar un dueño o propietario a la villa de Carranque es un ejercicio bastante inútil dada la documentación existente. Y empeñarse en ver lo español o el clan español del Emperador Teodosio es seguir haciendo una historia anacrónica o nacionalista".

85 Pedro Palol, La villa romana de La Olmeda de Pedrosa de la Vega (Palencia), Palencia, 1996, passim. 
Aquí el período de esplendor de las villae se inicia tardíamente, a mediados del siglo III d.C., y sobre todo, a lo largo del siglo IV, en plena época bajoimperial. Aunque la crisis del Estado romano ya empezaba a percibirse, las regiones periféricas como la Gallaecia no sufren tanto los avatares de la historia del momento como el mundo mediterráneo, por lo que esta etapa será de especial calma y progreso para la zona galaicorromana. La sociedad se encuentra ahora en plena madurez, y la mayor parte de las villae identificadas son fechadas en esta etapa, pudiendo destacar las zonas de litoral sobre las de interior para construir las villas. Las zonas costeras, para explotar los recursos marinos, tienen a mayores territorios fértiles como los valles fluviales que desembocan en el mar, además de las facilidades derivadas de la cercanía de redes de transporte y comercio marítimo.

Aquí se pueden citar los ejemplos de la villa de Centroña (Puentedeume, La Coruña), y la de Toralla (Vigo), recientemente excavada, siguiendo los consejos de Columela, 1.5.5-6 en cuanto a su correcta ubicación: "Eademque semper mare recte conspicit, cum pulsatur ac fluctu respergitur, numquam ex ripa, sed baud paulum summota a litore. Nam praestat a mari longo potius intervalo quam brevi refugisse, quia media sunt spatia gravioris balitus". Toralla está situada en la punta de un arenal a las afueras de la ciudad de Vigo, y además de la parte residencial se han encontrado los restos de unas salinas, lo que demuestra el carácter productivo de la villa. Su ocupación se ha situado cronológicamente entre el año 320 y el 420 d.C. gracias a la cerámica fina de importación encontrada en la misma. Es la única villa de todo el territorio de la Gallaecia que está musealizada.

Por otro lado, si nos se alude más en concreto a la configuración de las villae, a decir de algunos el más remoto antecedente del pazo gallego ${ }^{86}$, se puede señalar que fueron de dimensiones más reducidas que en el resto de la Península, bien porque la aristocracia indígena no fuera muy poderosa, ni tampoco lo fueran el resto de los possessores, aun enriquecidos por su trato con los romanos, bien por la tradición minifundista de la tierra, contraria a la concepción latifundista que imperaba en el resto peninsular ${ }^{87}$, de acuerdo con la geografía humana del territorio, pero también debido a los condicionantes de la topografía, poco apta para el latifundio según el patrón romano.

El noroeste, al igual que el resto del norte de España, nunca tuvo grandes núcleos de población, es decir, ciudades a las que proveer de los productos de

86 Antonio Blanco Freijeiro, "La villa romana en Gallaecia y su posible relación con la vita communis del priscilianismo", en Prisciliano y el priscilianismo, Los Cuadernos del Norte, Oviedo, 1982 , p. 57.

87 Vid. al respecto, NARCiso Vicente SANTOS YanGUas, "Las villas romanas en Asturias", MHA 4, 1984, p. 162, en donde se hace referencia a los asentamientos rurales existentes en torno a la ciudad de Gijón: "Se trata de un número bastante amplio de villae, que denotan una situación de cierto lujo, con distancias bastante cortas entre sí, por lo que es posible deducir que el territorio que les correspondería no debía de ser excesivamente extenso". 
las villae, por lo que la realidad de las villae hubo de adaptarse a las peculiaridades de la Gallaecia si quería introducirse como unidad socio-económica real, construyéndose establecimientos rurales de dimensiones medianas o pequeñas con una importante vinculación entre la pars urbana y la zona rústica que se sitúa a poca distancia o incluso en el mismo edificio residencial. Por ello, la villa idónea para las zonas montañosas de Asturias y Galicia resultó ser la de "unidades separadas", o "villa de plan diseminado", consistente en un número variable de edificaciones domésticas reunidas, pero erigidas con independencia dentro de la villa. En favor de la planta diseminada de la villa, Vitruvio ${ }^{88}$ advertía de su eficacia como medida de precaución contra el peligro de incendio, citando entre los diversos elementos constructivos el característico hórreo que aún hoy representa el paisaje de la Gallaecia: "Horrea, fenilia, farraria, pistrina extra villam facienda videntur, ut ab ignis periculo sint villae tutiores".

Un ejemplo de este tipo de villas lo representa Las Murias de Beloño ${ }^{89}$ (Gijón, Asturias), en la orilla izquierda del río Argemide, establecimiento rural constituido por tres edificios dispuestos en torno a un espacio central identificados como un sector residencial, con galería de fachada, un conjunto termal y un sector rústico, ocupada hasta el siglo VI, como evidencian los materiales cerámicos encontrados en las misma.

La villa de Veranes (Gijón), es una de las villae excavadas sistemáticamente durante los últimos años en el norte hispano, lo cual supone un avance con respecto a los intereses investigadores del pasado reciente, centrados en enclaves urbanos, zonas de explotación minera, como las Médulas (castros-poblados mineros), y en la presencia militar. Su ubicación cumple con las indicaciones de los agrónomos latinos en cuanto a su construcción, siguiendo las recomendaciones de Varrón, 1.12.1, cuando señala que lo más conveniente es construir la villa al pie de una colina, y preferentemente a media altura: "Danda opera ut potissimus sub radicibus montis silvestris villam ponet", a la falda de un monte poblado de árboles, ya que Veranes se levanta sobre una suave ladera orientada al sur, localizada a unos 800 metros de un ramal transmontano de la Ruta de la Plata, que era la vía romana que conectaba Gijón con Lucus Asturum y Asturica Augusta.

Además, desde el punto de vista topográfico tiene una posición privilegiada, ya que está protegida de los vientos del norte, con los beneficios climáticos que ello supone, como indica el propio Columela, 1.4.10: "Petatur igitur aer calore et frigore temperatus, qui fere medios obtinet colles, quod neque depressus bieme pruinis torpet aut torret aestate vaporibus", y el espacio visual que abarca es muy amplio ${ }^{90}$, lo

89 Francisco Jordá Cerdá, Las Murias de Beloño (Cenero, Gijón). Una villa romana en Asturias, Oviedo, 1957, passim

90 Vid. CaRmEn Fernández OChOA y FeRnANDo Gil SENDINO, "La villa romana de Veranes (Gijón, Asturias) y otras villas de la vertiente septentrional de la cordillera cantábrica", en Las villae tardorromanas en el occidente del Imperio, cit., pp. 437-438. 
que ayuda también a una mayor seguridad en todos los sentidos, pues, como dice Varrón, 1.12.4: "Nimbi repentini ac torrentes fluvii periculosi illis, qui in bumilibus ac cavis locis aedificia babent, et repentinae praedonum manus quod improvisos facilius opprimere possunt, ab baec utraque re superiora loca tutiora", evitando así quienes se resguardan en lugares elevados el riesgo de inundaciones y de ladrones que puedan asaltarles de improviso.

Este complejo rural tuvo una ocupación dilatada en el tiempo, desde la segunda mitad del siglo I d.C. hasta la segunda mitad del siglo V d.C., momento en el que, de acuerdo con las investigaciones arqueológicas, se advierte el primer síntoma de abandono de la villa, dedicando dicho espacio a nuevas funciones. En lo que se refiere a la villa tardorromana, podemos apreciar que se trata de una explotación de tamaño mediano, si la comparamos con los grandes fundi imperiales, controlada por un dominus, o en su nombre por el vilicus o administrador, y en régimen de colonato, y ampliada con nuevos espacios donde la ostentación reflejaba el nuevo estatus de esta aristocracia terrateniente.

Se cree que el señor de este fundus se llamaba Veranius, nombre que aparece con frecuencia en la onomástica latina de Hispania ${ }^{91}$, pero no se conoce la relación que mantenía con el núcleo urbano de Gijón, cuya vitalidad durante la época tardorromana parece fuera de toda duda, a diferencia de lo sucedido con otras ciudades hispanas. A mediados de la cuarta centuria se desarrolló el tercer proyecto arquitectónico de Veranes, que confirió al complejo un carácter monumental, y que permite encuadrarla dentro de las villas de plano compacto o villas de patio, siendo el patio el elemento unificador de la villa ${ }^{92}$.

Para ayudar a reforzar la posición del dominus, a fin de poder recibir a su clientela de forma adecuada que también reforzase su poder, se cree que el ceremonial de los visitantes de Veranes comenzaba recorriendo el vestíbulo, y un pasillo de pequeñas dimensiones, hasta llegar a una galería porticada abierta al sur, que conducía a los espacios destinados a la vida pública, situados al fondo del corredor, cuyo extremo lo formaba el salón de la diaeta del dominus. A través de un arco y escaleras, los clientes y visitantes accedían a la sala de audiencias, de grandes dimensiones, compuesta por una nave rectangular, y el oecus, que preside desde arriba el conjunto ${ }^{93}$. De este modo, quedaba claro el ambiente de superioridad y sumisión de todo aquel que conseguía mantener una audiencia con el señor de la villa de Veranes.

91 Juan Manuel AbaSCAL, Los nombres personales en las inscripciones latinas de Hispania, Murcia, 1994, p. 245.

92 M. C. Fernández CaStro, Villas romanas en España, cit., p. 164: "La villa entendida como vivienda de un establecimiento agrícola se integra con frecuencia en un conjunto de edificaciones dependientes de la actividad de producción. Estas construcciones anexas a la villa suelen presentarse en un espacio abierto frente a la vivienda o en sus inmediaciones".

93 Carmen Fernández Ochoa y Fernando Gil Sendino, "La villa romana de Veranes (Gijón, Asturias) y otras villas de la vertiente septentrional de la cordillera cantábrica", cit., p. 446. 
Por último, en cuanto a la presencia de los visigodos en las villae, debemos decir que es probable que parte de la población visigoda se instalase en las villas confiscadas o abandonadas por los propietarios romanos, pero no se tiene información arqueológica ni documental suficiente que ayude a identificar esta posible permanencia visigoda en las villae ${ }^{94}$, a diferencia de lo que ocure respecto de otras zonas como Italia (donde la presencia longobarda se identifica claramente gracias a tipologías cerámicas particulares), por lo que se debe ser prudentes al hablar de la posible ocupación de un villa por parte de individuos no romanos, ya que, muy al contrario, las transformaciones tardías de las villae hablan de población hispanorromana como residente en las mismas ${ }^{95}$.

\section{LA PRESENCIA MILITAR}

En una etapa sobre la que existe muy poca información, resulta especialmente difícil concretar el papel desempeñado por el ejército romano en la Hispania del Bajo Imperio, y por ende en la defensa y salvaguarda de su territorio. La realidad de villas y ciudades tardoantiguas sería distinta si la función clásica del ejército como defensor de las fronteras se hubiese desarrollado correctamente. Pero la escasa documentación al respecto ofrece un panorama desolador en cuanto a la irregularidad de la presencia del ejército en nuestro territorio, así como en lo que concierne a las disfunciones con respecto al número de efectivos, organización de los mismos y compromiso con la estructura militar a la que pertenecían, ya que el número de deserciones era sumamente frecuente.

Ahora ya no resultan necesarias legiones que vigilen de manera permanente las explotaciones mineras del noroeste hispano ${ }^{96}$, como sucedió con la Legio VII Gemina a finales del siglo II, cuando tenía su campamento en Legio (León), en la Hispania Citerior Tarraconense. Aun cuando parte de la doctrina siga reconociendo la presencia en el noroeste peninsular de efectivos militares

94 Aunque se haya encontrado, por ejemplo, en San Julián de Moraime, Muxía, Costa de la Muerte, cerca de la Coruña, una placa de cinturón de bronce de perfil liriforme (¿siglo VII?) y una cruz de bronce grabada, referencia a fíbulas de guerreros suevos, dentro de una de las sepulturas.

95 Alexandra Chavarría Arnau, "El final de las villae en Hispania", cit., p. 74, en donde se añade en p. 75: "las pocas ocasiones en que se puede relacionar una presencia bárbara a una determinada villa se debe a la existencia de conjuntos funerarios visigodos sobrepuestos a un edificio".

96 Vid. al respecto, RichaRd F. JONES, "The Roman Military occupation of North-West Spain", JRS 66, 1976, pp. 45 ss.; MARÍA José BraVo BOSCH, "Marco jurídico de las minas del noroeste hispano", en Hacia un Derecho Administrativo y Fiscal Romano, ANTONIO FERNÁNdez De Buján, Gabriel gerez Kraemer y Belén Malavé Osuna (eds.), Madrid, 2011, pp. 227-250. 
destinados a la defensa de las zonas auríferas ${ }^{97}$, debemos ser claros al señalar que estas minas dejaron de explotarse en el siglo II d.C., lo que hace difícil pensar en la necesaria participación del ejército romano para la defensa de unas zonas mineras ya abandonadas.

Del mismo modo, y abundando en la presencia de las legiones romanas contra las posibles incursiones de Cántabros, Astures y Vascones, se ha querido ver por parte de algunos historiadores un limes $^{98}$ como frontera asignada a las tropas presentes en la Península, teoría que acá no se comparte por el argumento antes señalado y por no corresponder con la realidad del siglo IV. El convertir a los limitanei $^{99}$ creados por Diocleciano, como se verá a continuación, en titulares de la potestad de defensa de un limes preexistente se basa en la interpretación de la descripción de efectivos militares recogidos en la Notitia Dignitatum ${ }^{100}$-documento fechado convencionalmente en el año 395 d.C. ${ }^{101}-$, en la que su autor, en el intento de proponer el escenario más propicio

97 Alberto BaliL, "La defensa de Hispania en el Bajo Imperio", Zephyrus, vol. 11, 1960, p. 179.

98 Abilio Barbero y Marcelo VigiL, "Sur les origines sociales de la Reconquête: cantabres et vascons de la fin de l'Empire Romain à la fin de l'invasion musulmane", Boletín de la Real Academia de la Historia (BRAH) 156, 1965, pp. 271 ss.; José MARÍA BLÁZQUEZ, "Rechazo y asimilación de la cultura romana en Hispania (siglos IV-V)", en Assimilation et résistance à la culture gréco-romaine dans le monde ancien. Travaux du VIe Congrès International d'Études Classiques, Madrid, 1974, Bucarest y París, 1976, p. 70: "Ya a partir del siglo III, estas organizaciones indígenas y algunos pueblos que las tenían, debieron, en gran parte, escapar al control de Roma y con seguridad durante los siglos siguientes en Asturias, Cantabria y Vasconia por lo menos, lo que explica la aparición de un limes contra los pueblos del N. de la Península Ibérica. La existencia de este limes se ha deducido de la Notitia Dignitatum Occidentis (VII, 119-124; XLII, 26-32) y de los datos suministrados por la Arqueología".

99 Vid., sobre el significado preciso del término, BEJAMIN ISAAC, "The meaning of the term limes and limitanei", JRS 78, 1988, p. 139: "In the late empire part at least of the troops serving on the frontier were called limitanei. A reconsideration of the meaning of limes will therefore also be relevant for that of limitanei, since the nature and organization of these forces bave been a subject of controversy, it may be useful to review the available information", concluyendo en p. 146, que los limitanei "were simply soldiers serving anywhere in the area assigned to the relevant dux and their duties were not necessarily connected with frontier defence. The task of these troops was to take care of road security, mainly in the frontier districts, but they could be stationed elsewhere as well".

100 Véanse sobre este documento los trabajos de referencia, como JOHN BAGNELL BURY, "The Notitia Dignitatum", JRS 10, 1920, pp. 131-154, ARNOLD Hugh MARTIN JONES, The Later Roman Empire, II, 1964, p. 1417: "The Notitia Dignitatum presents a number of unsolved and perbaps insoluble problems, but any bistorians of the later Roman empire must take the utmost posible use of so valuable a document, and in order to do so must take up a provisional position on the questions of its composition"; MICHAEL KULIKOWSKI, "The Notitia Dignitatum as a Historical Source", Zeitschrift für Alte Geschichte, 49, 3, 2000, p. 358: "The Notitia Dignitatum is a peculiar, illustrated list which itemises the administrative bierarcby, both civil and military, of the late Roman empire. It is our greatest surviving source for the bureaucracy of that empire, but it is a unique source and nothing comparable to it survives from its epocb".

101 Aunque la fecha es motivo de controversia, ya que mientras en ARNOLD HugH MARTIN JONES, The Prosopography of the Later Roman Empire: vol. 2, AD.395-527, Cambridge, 1980, pp. 
para el Imperio ${ }^{102}$, seguramente utilizó una información desfasada en lo que se refiere a la disposición del ejército en la Península Ibérica ${ }^{103}$, careciendo del valor documental suficiente para el conocimiento del ejército romano de la Hispania del Bajo Imperio. El capítulo XLII de la Notitia Dignitatum que se refiere a Hispania es el siguiente:

Not. Dig.Occ. XLII, 25 ss.:

25. In provincia [Hispaniae] Gallaecia

26. Praefectus legionis septimae geminae ${ }^{104}$, Legione

27. Tribunus cobortis secundae Flaviae Pacatianae, Paetaonio

28. Tribunus cobortis secundae Gallicae, ad cobortem Gallicam ${ }^{105}$

29. Tribunus cobortis Lucensis, Luco

30. Tribunus cobortis Celtiberae, Brigantiae, nunc Iuliobriga

31. In provincia Tarraconensi

32. Tribunus cobortis primae Gallicae, Veleia ${ }^{106}$

1211 ss., se apuesta por el año 395, en ANDRÉ CHASTAGNOL, "Les gouverneurs de Byzacène et de Tripolitaine", Antiquitès Africaines 1, 1967, p. 131, la fecha correcta está entre el 425 y el 428, y en ARCE, Bárbaros y Romanos en Hispania. 400-507 A.D., cit., p. 198, sin concretarse demasiado, se habla de su redacción "en los primeros años del siglo V".

102 Peter Brennan, "The Notitia Dignitatum", en Les Littératures techniques dans l'Antiquité romaine, Ginebra, 1995, pp. 147-148.

103 JaVIER ARCE, Bárbaros y Romanos en Hispania. 400-507 A.D., cit., p. 199: "La corriente de opinión más generalizada entre los investigadores de la Notitia va cada vez más en esta dirección, es decir, en [la de] considerarla un documento que no refleja la realidad que propone, un texto que se ofrece al emperador, ricamente ilustrado a todo color, un estado ideal de la situación del Imperio".

104 Antonio García y Bellido, "La legio VII Gemina Pia Felix y los orígenes de la ciudad de León", Boletín de la Real Academia de la Historia 127, 1950, p. 453: "Su primer adjetivo, el de Gemina, aparece más tarde y tampoco fue puesto por Galba; ni aun siquiera en tiempos de Galba. Su origen preciso no se sabe con certeza. Se había sospechado que procedía del hecho supuesto de que parte de los contingentes que formaron la legio I Macriana disuelta por Galba, habían ido a fundirse con los de la VII por él fundada. Pero esta hipótesis carece de toda probabilidad. Más aceptable es la que hace proceder el epíteto de Gemina de la batalla de Cremona, en la que la legión sufrió pérdidas tan considerables que se debió de hallar en la necesidad de completar sus cuadros con restos de otras legiones también diezmadas. Es posible que estos componentes procediesen de vexillationes oriundas de alguna legión británica o germánica. Es entonces cuando pudo haber motivos sobrados para darle a la legio VII el apellido de Gemina, viene a querer decir 'doble', 'acoplada'; en tal caso debió de adquirirlo después del mes de abril del año 69, fecha en la que ya hacía unos tres meses que había muerto Galba".

105 José MARía BláZQUEZ, "Rechazo y asimilación de la cultura romana en Hispania (siglos IV-V)", en Assimilation et résistance à la culture gréco-romaine dans le monde ancien. Travaux du VIe Congrès International d'Études Classiques, cit., p. 71: "La Cobors I Gallica se encontraba ad Cobortem Gallicam, lugar no identificado de Galicia".

106 Vid. al respecto, Antonio García y Bellido, "El Exercitus bispanicus desde Augusto a Vespasiano", AEA 34, 1961, pp. 114 ss., en donde se sitúa la legión y sus cohortes con 
Al margen de otras consideraciones, como el hecho de que en este capítulo no se menciona (como tampoco en ningún otro) ningún dux para Hispania ${ }^{107}$, cuando es sabido que los ejércitos de frontera eran dirigidos por duces, así como los comitatenses por comites, el contenido de la Notitia Dignitatum no es fiable y lo que hace es reproducir situaciones no existentes ya en la Hispania del siglo $\mathrm{V}$, por cuanto el ejército que permaneció en Hispania a partir del siglo II no es el ejército oficial estable que había en tiempos de Augusto, sino un ejército de campesinos-soldados dedicados a diversos menesteres, como

una localización determinada cuando es posible. Así, la Legio VII Gemina se corresponde con la ciudad de León, como confirma constantemente el autor en cita en sus numerosos trabajos, pudiendo mencionar, entre otros: "Nuevos documentos militares de la Hispania romana", AEA 39, 1966, p. 28, en donde al referirse a la Legio X Gemina, se declara: "es muy probable que estuviera en la región de Astorga, acaso en el mismo lugar donde, tras su marcha, había de acampar luego la Legio VII Gemina, es decir, en León"; y con respecto a su fecha de creación, "León y la Legio VII Gemina con motivo del XIX centenario de su creación", Tierras de León, 7, 1966, p. 17: "Los textos no precisan cuándo fue creada la legión. De ellos no se deduce sino el año, que fue el 68. Pero los epígrafes nos han suministrado la data exacta, es decir, el mes y el día. Efectivamente dos de las lápidas descubiertas en la iglesia de Villalís, provincia de León, a unos sesenta kilómetros al SO. de la capital, contienen la fecha precisa. Estas dos inscripciones fueron escritas una el año 163 y la otra el 184 de la Era para conmemorar el natalicio de la legión, es decir, el día y el mes en que ésta recibió las águilas e insignias (ob natalem aquilae). Según se dice en ellas, el acontecimiento hubo de tener lugar el 4 de los idus de Junio, fecha que corresponde al 10 de Junio de nuestro calendario. Es muy posible que el acto de la creación tuviera lugar en Clunia. Así, pues, la Legio VII Gemina nació el 10 de junio del año 68 de la Era. Por caso realmente curioso resultó que la fecha de su orto precedió en un solo día a la muerte de Nero, contra el cual fue precisamente creada. Las águilas se dieron -repitámoslo- en el 10 de junio del año 68 y Nero murió el 9 del mismo mes y año. El ordinal VII lo recibió con respecto al de la legión compañera, aún en España, la Legio VI Victrix, con la cual se alzó Galba para derrocar a Nero y para proclamarse legado del Senado y Pueblo Romanos, en realidad emperador. De este modo Galba distinguió la fidelidad de la VI Victrix haciendo caso omiso de la ya existente Legio VII Claudia"; la II Flavia Pacatiana se sitúa en Paetaonium, Rosinos de Vidriales, en la provincia de Zamora, en la p. 143 de El Exercitus bispanicus desde Augusto a Vespasiano, cit., se habla de la II Gallica, sin identificar: "No poseemos otros datos más que el que se deduce de la mención, es decir, que estaba de guarnición en Galicia en las postrimerías del Imperio"; con respecto a la cohorte Lucensis, García y Bellido declara que es probable que haya estado de guarnición en el noroeste, pues en Lucus Augusti, actual Lugo, de donde procede el nombre de la unidad, se encontró un hito funerario de un mili. corti (sic) tertia Luces (CIL II 2584). Como la Not. Dign. Occ. 42, 29 menciona una cob. III Lucensium, es natural deducir que se trata de la misma; la cobors Celtiberorum en Iuliobriga se corresponde con Reinosa, en la provincia de Santander, y la I Gallica, estudiada por ANTONIO GARCía Y BELLIDO, en "Cohors I Gallica equitata Civium Romanorum", Conimbriga 1, 1959, pp. 29 ss., en donde se la sitúa dentro del conventus Braccaraugustanus.

107 Vid. JaVIER ARCE, "La Notitia Dignitatum et l'armée romaine dans la diócesis Hispaniarum", Chiron 10, 1980, p. 608, cuando al negarse la existencia de un limes, se afirma: "Dans ce cas, le commandement militaire aurait dû être aux mains de comités ou de duces qui, dans la Notitia, n'existent pas dans la diócesis Hispaniarum". 
tareas administrativas, represión del bandidaje, protección de gobernadores $y$, eventualmente, acciones de defensa ${ }^{108}$.

Diocleciano (284-305) fue conservador en sus ideas militares, por lo que decidió continuar con una política claramente defensiva. De este modo, incrementó notablemente el número de efectivos en el ejército ${ }^{109}$, así como la defensa de las fronteras con fortificaciones y caminos ${ }^{110}$. En un conocido pasaje de Zósimo ${ }^{111}$ se aprecia el contraste entre la política militar de Diocleciano y la de Constantino. Así, mientras Diocleciano optó claramente por la defensa de las fronteras del Imperio, Constantino (306-337) reorganizó el ejército, impulsando un gran desarrollo al ejército de maniobra.

Ahora se cambia la estrategia defensiva, con nuevos destacamentos y unidades auxiliares, y dividiendo las antiguas guarniciones legionarias, por lo que cabe decir que se está ante un nuevo ejército, articulado en dos nuevos cuerpos: limitanei o ripenses y más tarde, con Constantino, los comitatenses, con un nuevo cometido además como policía fiscal y militar. Estaban dotados con unidades de infantería y caballería, con funciones diferentes, ya que mientras la infantería servía para desplazarse a lo largo de la frontera -de ahí el nombre de limitanei- allí donde se le requiriesen sus servicios, el comitatus ${ }^{112}$ estaba integrado por fuerzas móviles que acompañaban al emperador en sus desplazamientos y se encontraban dispuestas para sofocar posibles revueltas.

En lo que se refiere a la táctica militar utilizada por el ejército romano del Bajo Imperio, siguiendo una política estratégica de defensa elástica, se construyeron fortificaciones de ciudades no entendidas como plataformas de combate desde un punto de vista militar sino como defensa de nudos de

108 JaVIER ARCE, Bárbaros y Romanos en Hispania. 400-507 A.D. cit., p. 199.

109 Vid. Lactancio, De mort. Pers. 7.2, en donde dice que el emperador multiplicó en exceso el número de soldados; y JuAn José SAYAS ABEngochea, Historia antigua de la Peninsula Ibérica, Madrid, 2003, p. 329, en donde se declara que el pasaje de Lactancio constituye una gran exageración, ya que si bien "es cierto que el número de legiones pasaron de 39 a $60^{\prime \prime}$, redujo los efectivos de cada legión.

110 Vid. al respecto, DenIS VAN BERCHEM, L'Armée de Dioclétien et la réforme constantinienne, París, 1952, passim.

111 Zos. II, 34.

112 JuAn JosÉ SAYAS, "La administración en el Bajo Imperio", AA.VV., Historia de España Antigua, 2, Hispania Romana, 3. ${ }^{\text {a }}$ ed., Madrid, 1988, p. 530: "El comitatus estaba compuesto por miembros oficiales y por miembros no oficiales. Los miembros oficiales eran de dos clases: civiles (comes et quaestor, comes et magister officiorum comes sacrarum largitionum, comes res privatae y los prefectos del pretorio) y militares (los magistri militum praesentales, los oficiales palatinos, los comites domesticorum $\mathrm{y}$, con posterioridad, el comes excubirorum). A esto hay que añadir un número variable de personas que no debían pertenecer a él por derecho y que en su mayoría habían formado ya parte del consistorio como miembros de pleno derecho. Por razones de utilidad se creía conveniente su continuidad en el mismo como miembros no oficiales. Algunas personas que habían desempeñado cargos administrativos cualificados eran llamadas a formar parte de él también como miembros no oficiales". 
comunicaciones o centros económicos. La estrategia empleada se impuso de acuerdo con la creencia de que los defensores de la civitas se enfrentarían con enemigos sin la instrucción militar adecuada para sitiar a la ciudad y atacarla con el armamento pesado necesario para la victoria, lo que daría tiempo a las fuerzas de contraataque para acudir al rescate de las ciudades fortificadas. Evidentemente estas fortalezas resultaban útiles ante el ataque de las hordas bárbaras del siglo III d.C. Pero cuando surgieron guerras civiles, en el enfrentamiento entre ejércitos regulares o las invasiones del siglo $\mathrm{V}$, tales fortificaciones fueron sometidas por los bárbaros, mediante el sitio prolongado de las mismas ${ }^{113}$.

Además, a Diocleciano y Constantino debemos la separación de las funciones civiles y militares en la administración ${ }^{114}$, con la consiguiente repercusión importante en el campo administrativo y político, ya que para los oficiales del ejército dejaron de tener interés los cargos civiles en la administración imperial y para los funcionarios dejó de tenerlo la carrera militar. Este mimetismo en la esfera política o militar, y administrativa o burocrática, ha sido interpretado como la conversión de los soldados en propietarios y de los propietarios en soldados $^{115}$. Con todo, el problema reside en la falta de documentación sobre este proceso en Occidente, donde no se prodigan las fuentes que acrediten adquisiciones de tierra por parte de soldados, aunque ello no signifique que no fuesen propietarios como en Oriente ${ }^{116}$.

113 Alberto BaliL, "La defensa de Hispania en el Bajo Imperio", Zepbyrus, 11, 1960, p. 182: "Su concepción militar atendía sólo a sitios breves, de pocos días o pocas semanas, olvidando el eterno problema de las plazas sitiadas, que es contar al mismo tiempo con suficientes defensores y suficientes medios para alimentar a éstos y a la población civil. Por ello estas fortificaciones, pese a su innegable solidez, comprobada cuando fueron utilizadas contra ellas armas de fuego, no evitaron que paulatinamente las ciudades cayeran en poder de los bárbaros, no tanto por resultado de un asalto, sino por efectos de un asedio prolongado".

114 Vid. Adolfo Raúl menÉndeZ argüIn, De Septimio Severo a Diocleciano (193-305 D.C.), Sevilla, 2011, p. 31, en donde al hacer referencia a Diocleciano se declara: "Una de las actuaciones más importantes dentro de la administración provincial fue la de despojar a los gobernadores de sus atribuciones militares".

115 Dick WHITTAKER, "Landlords and Warlords in the Later Roman Empire", en J. Rich y G SHIPLEY (eds.), War and Society in the Roman World, Londres, 1993, p. 277: "Soldiers turning into landlors and landlords becoming soldiers".

116 GonZalo Bravo, "Ejército, agitación social y conflicto armado en Occidente tardorromano: un balance", Polis. Revista de ideas y formas políticas de la Antigüedad clásica 19, 2007, p. 15: "Pero ello no significa que los soldados no fueran propietarios de tierras, sino que, por el contrario, la alusión a sus tierras o posesiones se explica precisamente por tratarse de campesinos - pequeños propietarios de tierras o colonos libres- que no habían podido sustraerse a la conscripción mediante pago, huida o protección. Quizá por la misma razón, el patrocinio militar, que está bien documentado en Oriente, no está documentado de forma expresa en Occidente, aunque algunos casos como el de Merobaudes en la Bética o el de Jovino en la Galia pueden encubrir esta situación". 
Por lo que se refiere a la composición del ejército bajoimperial ${ }^{117}$, se debe dejar constancia de la inexistencia de campesinos o provinciales en el ejército del siglo IV, compuesto fundamentalmente por fuerzas mixtas, por romanos y bárbaros ${ }^{118}$, e incluso, en varias ocasiones, por ejércitos bárbaros que actuaban como federados de los romanos ${ }^{119}$. Es decir, el ejército romano regularmente constituido por legiones de cives romanos y tropas auxiliares había perdido casi todas sus funciones tradicionales ${ }^{120}$, como estar en la retaguardia del combate iniciado por las tropas auxiliares, intervenir activamente en la batalla al mando de un general romano o destruir al ejército enemigo ${ }^{121}$.

Llegados a este momento, los que comandaban el ejército imperial, ya fueran generales o usurpadores, debían reclutar sus propios soldados para reforzar a la tropa, llegando incluso a pedir ayuda militar a los bárbaros ${ }^{122}$, asentados en

117 Yann Le BOHEC, El ejército romano, trad. esp., Barcelona, 2006, p. 361: "El ejército del Alto Imperio presentaba tres características fundamentales: la estrategia del limes, con el ejército instalado en las fronteras, un encuadramiento aristocrático y un reclutamiento de calidad. Podemos definir el ejército del Bajo Imperio utilizando los rasgos contrarios. A partir de mediados del siglo III, los oficiales ya no procedían del Senado. A continuación, Diocleciano sustituyó aquel principio basado en la calidad por otro que insistía en el aspecto cuantitativo".

118 Sobre la acepción de "bárbaro", y la evolución histórica del término, YVES ALBERT DAUGUE, Le barbare. Recherches sur la conception romaine de la barbarie et de la civilisation, Bruselas, 1981, passim; sobre la integración de los mismos, PURIFICACIÓn UbRIC RABANEDA, "La integración del bárbaro en la vida cotidiana del Imperio romano tardío", en Formas de integración en el mundo romano, GonZalo Bravo y Raúl GonZÁlez Salinero (eds.), Madrid, 2009, pp. 61 ss.

119 Vid. al respecto, EDWARD GiBBOn, The Decline and Fall of the Roman Empire, Chicago, 1932, p. 17, en donde se propone como motivo principal del final del ejército romano la incorporación de bárbaros al mismo, innovación propuesta durante el reinado de Constantino.

120 Tal vez por falta de calidad y disciplina de los nuevos militares del ejército tardorromano; vid. al respecto, STEPHEN DANDO-COLLINS, Legiones de Roma. La bistoria definitiva de todas las legiones imperiales romanas, trad. esp., Madrid, 2012, p. 627: "Vegecio, en un intento de aconsejar al emperador niño Valentiniano II (que reinó entre 371 y 392 d.C.) poco antes de que Roma cayera ante los bárbaros, se quejó de que el soldado romano de su época se había ablandado. Durante el reinado de 367-383 d.C. de Graciano, explicó, las legiones habían pedido permiso para quitarse la armadura, porque era demasiado pesada y, más tarde, también se habían despojado de sus cascos [Vege., MIR, 1]. 'Tomando ejemplo de los godos, los alanos y los hunos, hemos introducido mejoras en las armas de la caballería', dijo Vegecio, 'pero es evidente que la infantería está completamente indefensa"'; contra, Adolfo Raúl MenÉndez ArgüIn, De Septimio Severo a Diocleciano (193-305 D.C.), Sevilla, 2011, p. 198, en donde se afirma que el legionario romano iba perfectamente equipado y que "las protecciones corporales no se abandonaron ni aligeraron durante el siglo III d.C.; lo que se produjo a lo largo de este periodo fue una evolución auspiciada por nuevas tácticas y condicionantes socioeconómicos que desembocó en el ejército del siglo IV, pero en absoluto una disminución del equipo defensivo de los soldados".

121 Vid. GonZalo BRAVO, "Ejército agitación social y conflicto armado en occidente tardorromano: un balance", cit., p. 16

122 GonZALO BRAVO, “'Bárbaros romanizados? Nuevas fórmulas de integración del bárbaro en la sociedad bajoimperial", en Formas de integración en el mundo romano, cit., p. 33: "Pues bien, 
territorio romano, como laeti, gentiles o limitanei o grupos bárbaros que actuaban de modo autónomo en favor de la causa romana.

La composición de los ejércitos privados resultaba en general de lo más heterogénea, tanto como lo eran las fuerzas productivas de los predios y los habitantes de las ciudades. Se podían componer con elementos jurídica y socialmente distintos, por un lado con los habitantes del espacio de donde salían que dependían de los nobles que les convocaban.

La sociedad tardía optó claramente por el sistema de patrocinio que generaba la dependencia de los habitantes de un lugar de su señor mediante distintas modalidades ${ }^{123}$.

La liberación que suponía para los colonos ${ }^{124}$ la figura de la clientela con respecto a su patrón es inimaginable: agobiados por la presión fiscal ${ }^{125}$, por los abusos de los funcionarios de la administración, y las malas cosechas, hasta los ingenui llegaron a buscar el patrocinio en el campo dependiendo de un señor, a cambio de liberarse del trato con la administración, que ahora asumiría el nuevo patrón. Estos agricultores libres podrían engrosar las tropas de los diferentes ejércitos privados, ya que los colonos nacidos en los latifundios por generaciones estaban adscritos a la tierra y por lo tanto no podían prestar servicio en el ejército. También se utilizaban como mercenarios los habitantes más empobrecidos de las ciudades, e incluso hijos de militares obligados al ejército o a la curia en el caso de alegar invalidez ${ }^{126}$.

La capitatio y la iugatio resultaban insoportables como carga fiscal, y no había otra salida más que trasladar tal tributación al patrono, o servir en el ejército

desde comienzos del siglo IV el gobierno imperial parece haber modificado su política tradicional hacia los bárbaros, reclutando a grupos de éstos para reforzar sus efectivos militares o bien procurando su asentamiento en las zonas limitáneas. En el plazo de dos o tres generaciones la asimilación al modelo social romano de estos individuos fue tal que sólo mediante la onomástica podría distinguirse con seguridad a un personaje romano de otro de origen bárbaro".

123 Vid. SANZ, "Aproximación al estudio de los ejércitos privados en Hispania durante la Antigüedad tardía", cit., p. 240.

124 Vid. sobre el colonato tardío, y la política fiscal del bajo imperio, ANDRÉ DÉLÉAGE, La capitation da Bas-Empire, Mácon, 1945, passim; FrançOIS L. GANSHOF, "Le statut personel du colon au Bas-Empire. Observations en marge d'une théorie nouvelle", L'Antiquité classique, 14, 1945, pp. 261 ss.; sobre el colonato en tiempos de Justiniano, ADRIAAN JOHAN BOUDEWIJN SIRKS, "The Colonate in Justinian's Reign", JRS 98, 2008, pp. 120 ss.

125 Vid. Alfonso Agudo RuIZ, Estudios de Derecho Fiscal Romano, Madrid, 2016, p. 233, en donde al hablar de la posible apelación fiscal por parte de los particulares en el Bajo Imperio se afirma: "La ausencia de una disposición de carácter general reguladora del instituto de la apelación fiscal que le confiera un tratamiento unitario y orgánico, viene motivada por la constante preocupación de los soberanos de los siglos IV y $\mathrm{V}$ por aumentar los ingresos de la caja imperial, haciendo afluir a ella dinero público. En su lugar encontramos una regulación fragmentaria y a veces contradictoria", y a menudo nada favorable al principio de la apelación en las sentencias por causas fiscales.

126 C. Th. $7.1 .5,8 ; 22.1 .12$. 
para librarse de la presión fiscal ${ }^{127}$, situación elegida por los habitantes de un Imperio cada vez más debilitado, con un abuso flagrante de su posición especialmente en las provincias, como sucedió con la Hispania bajoimperial.

En la Notitia Dignitatum ${ }^{128}$ se encuentran testimonios de nombres de tropas auxiliares con etnónimo hispano, es decir que se pueden entender como exercitus bispanicus en sentido amplio, por contener en su denominación un nombre hispano, sin que ello implique que en sus filas haya en ese momento todo un contingente procedente de Hispania, puesto que aunque seguramente en su origen las tropas fueron levadas en territorio hispano, con el transcurso de los siglos no quedaría más que el nombre, porque los reemplazos serían efectuados con efectivos de procedencia diversa, como consecuencia de su traslado a otras zonas en función de los intereses militares de cada momento, y en aplicación del principio de conscripción territorial ${ }^{129}$. Así:

Not. Dig. Or. XXVIII, 36: cobors secunda Astarum (pro Asturum), Busiris;

Not. Dig. Or. XXXI, 43: ala secunda Hispanorum, Poisarietemidos;

Not. Dig. Or. XXXI, 58: cohors prima L<usitanorum >, Theraco.

Con todo, resulta llamativo que en un momento en el que se multiplican las unidades auxiliares, haya menos nombres de cohortes y alas con etnónimo hispano, reduciéndose a las que acabamos de señalar. Todas las cohortes asturum, con sus correspondientes numerales, se concentran en una sola ${ }^{130}$.

127 Vid. al respecto, ARnOld Hugh MarTin JONES "Capitatio and Iugatio", JRS 47, 1-2, 1957, p. 90: "The soldiers and veterans gain immunity for the personal capita of themselves and their wives (and parents), but the effect of this privilege is to reduce their liability to the regular land tax"; además, de acuerdo con lo previsto en C. Th. 7.20.4, los soldados tienen garantizada la inmunidad "for the capita of bimself, bis wife and parents, if they exist: but if be is an orphan bachelor be still gets immunity for the value of four capita, bis own caput and three mopre equivalent units of bis property, being only forbidden to convey bis immunity to another by assuming fictive ownership of bis property".

128 Edición de CONCEPCIÓN NEIRA FALEIRO, La Notitia Dignitatum. Nueva edición crítica y comentario bistórico, Madrid, 2006, pp. 245-246 para Not. Dig. Or. XXVIII, y p. 253-255 para Not. Dig. Or. XXXI.

129 NARCiSO ViCENTE SANTOS YANGUAS, "La cohorte I de caballería de los astures en el ejército imperial romano", Studia Zamorensia, 2. ${ }^{a}$ etapa, vol. VIII, 2008, p. 249, donde al hablar de la cohorte I de caballería de los astures y de sus últimos momentos de existencia, se afirma que ya "desde los siglos altoimperiales sus componentes se reclutarían entre las poblaciones más cercanas a sus sucesivos lugares de acampada. Por ello tal vez desde los años finales del siglo I apenas quedaría ya resto alguno de su origen astur si hacemos excepción de la denominación de dicha unidad militar, que se mantendría hasta los momentos finales de su existencia".

130 Vid. Sabino Perea YéBenes, "Documentación del exercitus bispanicus: soldados y oficiales de alas y cohortes con etnónimo hispano en inscripciones y papiros griegos. Prosopografía", Aquila Legionis, 7, 2006, p. 105, en donde se añade: "La cohors Asturum documentada en tiempos de Constantino (texto 51) tiene continuidad todo el siglo IV y en el V, si hacemos caso a la Notitia. Más curiosa es la recalificación de las cobortes Hispanorum, que son unificadas 
A mayor abundamiento, aunque a lo largo del siglo $\mathrm{V}$ persista la presencia del ejército romano en la Península Ibérica, ya no se trata de legiones estables en un sitio determinado, sino de ejércitos que acuden a una determinada misión defensiva desde la Galia, en cualquier acción contras suevos, alanos o vándalos. Además, las fuerzas romanas no son ya tropas regulares, sino que en la mayoría de los casos se trata de grupos bárbaros ${ }^{131}$, comandados por un general, bien romano o de origen bárbaro, al servicio de Roma para actuar como se les ordene en relación con los pueblos establecidos en la Península Ibérica desde el año $411^{[132]}$.

\section{CONCLUSIONES}

Con independencia de las conclusiones vertidas a lo largo del presente trabajo, se ha estimado conveniente hacer una serie de reflexiones finales que ayuden a la comprensión global de lo acaecido con el urbanismo y el territorio de la Hispania tardoantigua.

Las transformaciones experimentadas por los núcleos urbanos de la Antigüedad tardía demuestran un cambio conceptual con respecto al modelo de ciudad clásica romana. Pero ello no debe entenderse en el sentido de una clara decadencia de la vida urbana en el Bajo Imperio, porque no se corresponde con la realidad. La modificación sustancial de las ciudades debe entenderse dentro de un periodo de cambios, de una transición de una época a otra, sin denostar la realidad de la vida en las urbes bajoimperiales. Bien es cierto que los cronistas cristianos dejaron testimonio de la barbarie, pero todo ello ha de entenderse en un contexto de profundos cambios, incluido el religioso.

y transformadas en una única ala de caballería en la Notitia, algo que no debe sorprender, pues la cohors II Hispanorum es mixta, equitata, a partir de las últimas décadas del siglo II d.C.".

131 Considerados como uno de los motivos de la decadencia del Imperio romano, como declara JUAN JOSÉ SAYÁS, "La conciencia de la decadencia y caída del imperio por parte de los romanos", en M. FERNÁNDEZ-GALIANO et al., La caída del Imperio Romano de Occidente en el 476, Madrid, 1980, p. 54: "Indudablemente es válida la consideración de los escritores antiguos de que la progresiva barbarización del ejército y de los servicios administrativos era uno de los factores de la decadencia de Roma. Ahora bien, la barbarización del Imperio era un indicio de que Roma necesitaba hombres que realizasen determinadas tareas de administración y defensa que no podían cumplimentar debidamente los propios Romanos por causas difíciles de concretar, sobre las que también han aportado datos algunos autores antiguos e historiadores modernos para considerarlas como causas primeras de decadencia. Se apunta, por ejemplo, hacia una supuesta necesidad creciente de hombres para la producción y los servicios, o bien hacia una causa todavía más negativa, un descenso de la natalidad fomentado aparentemente por el Cristianismo".

132 Vid. JaVIer ArCe, Bárbaros y Romanos en Hispania. 400-507 A.D., cit., p. 197, en donde se añade: "Otras veces los ejércitos romanos están compuestos de tropas mixtas, en las que los auxilia godos o de otros pueblos, constituyen un componente esencial y decisivo para la campaña". 
La verdad es que la arqueología ha brindado maravillosos ejemplos de pervivencia de las ciudades en la Hispania del Bajo Imperio que incluso respetan la fisonomía clásica anterior, al margen de las variaciones necesarias como consecuencia del sistema de poblamiento ${ }^{133}$, cada vez más presente en el núcleo urbano. La lenta transformación del tejido urbano tendrá además una amplia variabilidad local, ya que, como se ha podido constatar, la realidad del norte peninsular no tiene nada que ver con el resto de Hispania.

Con todo, y de un modo general, la ciudad tardoantigua estará gobernada por un nuevo orden urbanístico, caracterizado por una progresiva ocupación de la vía pública, la desurbanización del área residencial intramuros, la reconversión de estructuras públicas en espacios domésticos, cambios en el saneamiento, abandono de la red de alcantarillado, así como la aparición de basureros urbanos intramuros de la ciudad, en clara relación con la densificación de la población residente de las ciudades, lo que provocará a su vez la desertización del territorio.

Del mismo modo, la regulación de la vida en las villas y ciudades de la Antigüedad tardía se contempla pormenorizadamente en el Código Teodosiano y en diferentes normas legales destinadas a imponer más que a permitir, con una exigencia exagerada de tributos a los habitantes que hace cada vez más asfixiante la situación de los mismos. La presión fiscal les conducirá paradójicamente a abandonar poco a poco los núcleos urbanos densamente poblados para dirigirse al campo, en donde transferirán sus cargas a un patrono comprometido a resolver sus asuntos frente a la administración a cambio de su propio trabajo ${ }^{134}$.

Este cambio de modelo se da sobre todo en las villas, también de diversa condición en la realidad hispana y con contrastes absolutos entre las distintas villas existentes en nuestro territorio. No será lo mismo una villa atlántica situada en el noroeste peninsular, con dimensiones reducidas y destinada a pequeñas explotaciones de productos sobre todo procedentes del mar, como salinas ${ }^{135}$,

133 Independientemente del cómputo global de población en el Bajo Imperio, ya que a pesar de las guerras y las enfermedades, Hispania se mantuvo en los márgenes poblacionales habituales, como se recuerda en R. TEJA, "Economía y Sociedad en el Bajo Imperio", en AA.VV. Historia de España Antigua, 2, Hispania Romana, cit., p. 539: "Creemos, pues, que el siglo IV se enmarca entre dos períodos en que se produjo un ligero descenso demográfico, pero a lo largo del siglo la población no debió de variar sensiblemente de la que había existido en los dos primeros siglos del Imperio".

134 Vid. Benjamín Wells, "Taxation and Bureaucracy in the Declining Empire", The Sewanee Review, 30,4,1922, p. 434, en donde se destaca la fuga de los grandes propietarios de las ciudades (al igual que hacían la mayoría de ciudadanos) como consecuencia de la presión fiscal: "In the West the cities drew broken men from the farms into their submerged proletariat, while large landlords showed a disposition to move out of the cities and live on their country estates, that so far as possible they might evade municipal burdens and taxes".

135 Fermín Pérez Losada, Adolfo Fernández FernándeZ y Santiago Vieito Covela, "Toralla y las villas marítimas de la Gallaecia atlántica. Emplazamiento, arquitectura y función", 
que las grandes villas mediterráneas o situadas en el interior, con hermosos mosaicos y distribuciones de espacios inimaginables en otras villas de pequeña explotación.

Con todo, es común al fenómeno de las villas la fecha de su apogeo en el siglo IV, ya que mientras en la mayor parte del mundo romano las villas tienen su mayor esplendor a finales de la República y principios del Imperio, en Hispania las villas florecen en el Bajo Imperio ${ }^{136}$. Uno de los motivos principales del éxito de estas construcciones reside en la economía hispana de este período, que se basaba sobre todo en las explotaciones ganaderas y agrícolas, y en la generalización de los latifundios como mejor ejemplo de las mismas ${ }^{137}$.

A mayor abundamiento, el ejército no se presenta tan organizado como antaño, carente de una dirección clara y de unos efectivos comprometidos con el servicio militar. Aparecen los mercenarios al servicio del mejor postor, y el ejército se va debilitando con la presencia de bárbaros integrados en el mundo romano, pero carentes de la disciplina militar tan presente en el pasado. Aquí sí debemos declarar sin ambages que el ejército tardoantiguo no se parece en nada al modelo ejemplar de tiempos de la República y la primera etapa Imperial, ya que nos encontramos con un conjunto de efectivos militares carentes de la disciplina, rigor y compromiso de antaño, con una profunda incapacidad para resolver los problemas militares de las fronteras y las provincias ${ }^{138}$, en

en Las villae tardorromanas en el occidente del Imperio, cit., p. 497: "Los edificios residenciales de la villa no se instalan, sin embargo, sobre la parte alta del cabo, sino prácticamente a nivel del mar sobre la ladera interior del mismo, orientados precisamente hacia la marisma del Vao. Se sacrifica, por tanto, el condicionante habitacional de la prospectus maris -las magníficas vistas marinas sobre la ría que proporcionaría la primera ubicación- en favor de otros factores más prácticos y economicistas como son la elección de un emplazamiento más abrigado, protegido a poniente de la bocana de la ría por la elevación rocosa del cabo desde el que se domine y acceda fácilmente a los sectores productivos de la villas, esto es, las salinas de la playa y quizá también la propia ensenada del Vao".

136 Vid. al respecto, SimON KeAY, "Recent Archeological Work in Roman Iberia (1990-2002), JRS 93, 2003, p. 209, en donde se hace referencia a la fecha de declive de las villas en territorio hispano: "It is thus still not posible to stablish bow far the collapse of Roman power in Iberia in the late fifth century A.D. brought with it depopulation and the disintegration of the villa-based system that bad come to prevail in the course of the fourth and earlier fifth centuries, or to be able to say with confidence when villas might have been transformed into rural villages and monasteries".

137 José María BláZQUeZ, España romana, Madrid, 1996, p. 367, en donde se afirma en p. 372: "La mejor villa que ha dado Hispania, decorada con espléndidos mosaicos, es la de la Olmeda, Pedrosa de la Vega (Palencia), de finales del siglo IV o de comienzos del siglo siguiente, y que se ha supuesto que era de los primos de Honorio, que con gentes sacadas de su fundi lucharon tres años contra Constante".

138 Peter Heather, "Resistiendo al enemigo. Defensa de las fronteras y el bajo Imperio romano", en El arte de la guerra en el mundo antiguo. De las guerras persas a la caída de Roma, trad. esp., Barcelona, 2012, pp. 247-248: "En los enfoques tradicionales de la caída del Imperio romano se pone de manifiesto una actitud similar que se centra en gran medida en dilucidar si las estrategias fronterizas de los romanos fueron lo bastante inteligentes o suficientes para 
una situación de claro deterioro que conducirá a la desaparición del Imperio Romano de Occidente en el año $476^{[139]}$.

Todo ello nos conduce a la reflexión final, en la que se ha de dejar constancia de que una época de profundos cambios como la Antigüedad tardía debe ser visualizada y analizada en positivo, y no criticada en su misma esencia como ha venido haciendo la historiografía tradicional ${ }^{140}$. Es cierto que el caos resulta ser el protagonista en diversos momentos, debido en cierta medida a una mayor densidad de población que necesita una mejor planificación de la vida cotidiana en ciudades y villas, pero también es el tiempo de importantes transformaciones que modifican las relaciones socioeconómicas vigentes hasta

combatir la amenaza exterior. No obstante, una panorámica general de las pautas que se estaban desarrollando en cuanto a organización económica, social y política en la Europa central del período romano pone de relieve que es igualmente importante centrarse en lo que los llamados bárbaros estaban haciendo [...] [D]adas las condiciones que se estaban desarrollando sobre el terreno, el destino del imperio dependía fundamentalmente de lo que sucedía al otro lado de la frontera".

139 GonZalo Bravo (coord.), La caída del Imperio Romano y la génesis de Europa, Madrid, 2001, a modo de introducción en p. 3: "En Historia, los datos cronológicos tienen sólo un valor indicativo. Ni siquiera un acontecimiento trascendental como la desaparición política del Imperio Romano de Occidente en 476 es capaz por sí solo de delimitar con precisión los termini (final y comienzo) de una época. De hecho, el Imperio de Occidente había dejado de existir como tal varios decenios antes e incluso pervivió en cierto modo durante varias décadas después". Peter Heather, La caída del Imperio Romano, trad. esp., Barcelona, 2006, p. 543: "En el año 476 el Imperio romano de Oriente sobrevivió al hundimiento de su homólogo occidental y continuó prosperando, según todas las apariencias, a lo largo del siguiente siglo. En tiempos del emperador Justiniano I (527-565), concibió incluso un programa de expansión y conquista en el Mediterráneo occidental que aniquiló los reinos vándalo y ostrogodo del norte de África y de Italia y que arrebató parte del sur de Hispania a los visigodos"; añadiéndose después que aunque Gibbon afirma que el Imperio romano sobrevivió en el Mediterráneo oriental un milenio, haciendo coincidir su caída con la toma de Constantinopla por los turcos en 1453, en su opinión el crecimiento del islam en el siglo VII fue el que produjo una "fractura decisiva en la civilización romana del Mediterráneo oriental. Despojó al estado de Justiniano de las tres cuartas partes de sus ingresos y puso en marcha una reestructuración institucional y cultural de enormes proporciones".

140 Javier ArCe. "Antigüedad Tardía hispánica. Avances recientes", Pyrenae 36, 1, 2005, pp. 6-7 : "Podemos por tanto señalar de forma general que los estudios sobre la Antigüedad tardía en España han estado hasta hace pocos años dominados por la idea de la decadencia del Imperio y de la ruptura a finales del siglo IV, por la falta de análisis sistemáticos que tuvieran en cuenta las provincias de la diócesis como parte del conjunto amplio de la historia de las reformas de los emperadores de fines del siglo III y del IV, por el abandono del estudio del momento de implantación de los pueblos 'bárbaros' dejándolo para los especialistas en el 'mundo germánico', por la separación del estudio del Cristianismo y la organización eclesiástica de la historia de esta época. Sin embargo, la investigación plantea hoy día de forma clara y desde los más diversos puntos de vista, la interpretación de este período como una época de continuidad y lenta transformación, que afecta también, obviamente, a las provincias hispánicas y a su dinámica histórica". 
el momento ${ }^{141}$, para dar lugar a un nuevo modelo de vida ciudadano, aunque no transforme inmediatamente la sociedad.

No se debe deformar la realidad, sino constatar la vitalidad de una época de transición que condujo con el paso del tiempo al mundo feudal, a la edad media, tan distinta y distante del mundo romano conocido hasta entonces.

\section{BIBLIOGRAFÍA}

ABASCAL, JUAN MANUEL. Los nombres personales en las inscripciones latinas de Hispania, 1994.

Agudo Ruiz, Alfonso. Estudios de Derecho Fiscal Romano, Madrid, 2016.

ALFÖLDY, GÉZA. "El Imperio Romano durante los siglos II y III: continuidad y transformaciones", Tarraco christiana civitas, 2013.

Arce MartíneZ, Javier. "Antigüedad tardía hispánica. Avances recientes", en Pyrenae $36,1,2005$.

ArCe MartíneZ, JaVIeR. Bárbaros y romanos en Hispania (400-507 A.D.), Madrid, 2007.

ARCE MARTínEZ, JAVIER. El último siglo de la España romana, 284-409, Alianza editorial, 1982.

ARCE MartíneZ, JAVIER. "La villa romana de Carranque (Toledo, España): identificación y propietario", Gerión. Revista de Historia Antigua, 2003, vol. 21, n. 2.

ArCe Martínez, JaVier. "Villae en el paisaje rural de Hispania romana durante la Antigüedad tardía", en Villas tardoantiguas en el Mediterráneo occidental, Consejo Superior de Investigaciones Científicas, 2006.

Asensio, Sebastián F. Ramallo. "Carthago Spartaria, un núcleo bizantino en Hispania", Memorias de la Real Academia de Buenas Letras de Barcelona, 2000, vol. 25.

Balil, Alberto. "La defensa de Hispania en el Bajo Imperio", Zepbyrus, 2009, vol. 11.

Barbero Abilio, Vigil Marcelo, "Sur les origines sociales de la Reconquête: cantabres et vascons de la fin de l'Empire Romain à la fin de l'invasion musulmane", en Boletín de la Real Academia de la Historia (BRAH) 156, 1965.

Becerra, RaQuel Nodar; SÁnChez, Gilberto SÁnChez. "Reflexiones sobre las casas suburbanas en 'Augusta Emerita'", Mérida, excavaciones arqueológicas, 1997, n. ${ }^{\circ} 3$.

141 RAMÓN TEjA, "Economía y Sociedad en el Bajo Imperio", cit., p. 554: "Las transformaciones afectan principalmente a tres factores fundamentales: la distribución de la propiedad y la condición de la mano de obra, las relaciones ciudad-campo y el papel jugado en la economía por el Estado". 
BlÁZqueZ MartíneZ, JosÉ María. "El nombre de Hispania aparece en la historia. Los hispanos en el Imperio Romano", en De Hispania a España: el nombre y el concepto a través de los siglos, Temas de hoy, 2005.

BlÁZQUEZ MARTíneZ, JosÉ MARÍA. Rechazo y asimilación de la cultura romana en Hispania (siglos IV y V), 1976.

BlÁZQUeZ MartíneZ, JosÉ María. España romana, Madrid, 1996.

Blanco Freijeiro, ANTONiO. "La villa romana en Gallaecia y su posible relación con la Vita communis del priscilianismo", en Prisciliano y el priscilianismo, 1982.

Bravo BosCH, María José. "Marco jurídico en las minas del noroeste hispano", en Hacia un derecho administrativo y fiscal romano, Dykinson, 2011.

BRAVO BosCH, MARÍA JosÉ. "La protección del medio ambiente en la antigua Roma", Index: Quaderni camerti di studi romanistici, international survey of roman law, 2014, n. ${ }^{\circ} 42$.

Bravo, Gonzalo. La caída del Imperio Romano y la génesis de Europa, Madrid, 2001.

Bravo, Gonzalo. "Revolución y 'Spätantike': problemas de método en el análisis histórico de la sociedad tardorromana", Zephyrus 26-27, 1976, pp. 443 ss.

Bravo, Gonzalo. "¿Bárbaros romanizados? Nuevas fórmulas de integración del "bárbaro" en la sociedad bajoimperial", en Formas de integración en el mundo romano: Actas del VI Coloquio de la Asociación Interdisiciplinar de Estudios Romanos. Signifer Libros, 2009, pp. 31-44.

Brennan, Peter. "The Notitia Dignitatum", Les littératures tecbniques dans l'antiquité romaine: Status, public et destination, tradition, 1996.

Bury, John Bagnell. "The notitia dignitatum", Journal of Roman Studies, 1920, vol. 10.

Calzado, Miguel A. Alba. "Intervención arqueológica en el solar de la c/ Suárez Sotomonte, esquina con la c/ Sáenz de Buruaga: transición de un espacio doméstico y viario de época romana a la tardoantigüedad", Mérida, excavaciones arqueológicas, 1998, n. ${ }^{\circ} 4$.

Carlsson-Brandt, ERIK. "El poblamiento rural en la Galicia Romana. Un ejemplo: las villae. Metodología y Problemática en su estudio", Estrat crític, 2011, vol. 5, n. ${ }^{\circ} 1$.

Chavarría Arnau, AleXandra. El final de las villae en Hispania (siglos IV-VII d.C.), Brepols, Turnhout, 2007.

Chastagnol, André. "Les gouverneurs de Byzacène et de Tripolitaine", Antiquités africaines, 1967 , vol. 1, n. $^{\circ} 1$. 
Claude, Dietrich. Haus und Hof im Merowingerreich nacb den erzäblenden und urkundlichen Quellen, Vandenhoeck \& Ruprecht, 1997.

DANDO-COLLINS, STEPHEN. Legiones de Roma. La bistoria definitiva de todas las legiones imperiales romanas, trad. esp., Madrid, 2012.

DAUGUE, YVES ALBERT. Le barbare. Recherches sur la conception romaine de la barbarie et de la civilisation, Bruselas, 1981

De Heredia Bercero, Julia Beltrán. De Barcino a Barcinona, segles I-VII: les restes arqueològiques de la plaça del Rei de Barcelona. Institut de Cultura Museu D'Historia de la Ciutat Ajuntament, 2001

DÉLÉAGE, ANDRÉ. La capitation da Bas-Empire, Mácon, 1945.

Dupré RaVentós, XaVier y Remolà Vallverdú, Josep-Anton. "A propósito de la gestión de los residuos urbanos en Hispania", Romula, 2002, n. ${ }^{\circ} 1$.

Durliat, JeAn. Les finances publiques de Diocletien aux Carolingiens (284-888). Jan Thorbecke, 1990 .

FEIJOÓ, MANEL. "Imbricación de las élites laicas y eclesiásticas durante las transformaciones de la Antigüedad tardía overlap of the lay and ecclesiastic élites during the transformations of the late antiquity", en Antesteria, 2, 2013.

FERNÁNDEZ DE BUJÁN, ANTONIO. "Le role structurant des villes dans l'experience juridique romaine", en RGDR 13, 2009, disponible en: www.iustel.com

FernándeZ-Castro, María CruZ. Villas romanas en España. 1982.

FERnÁNDEZ-Galiano, Dimas. "Las villas hispanorromanas", en Cuadernos del Arte español, Madrid, 1998.

Fernández OChOA, Carmen y Gil Sendino, Fernando. "La villa romana de Veranes (Gijón, Asturias) y otras villas de la vertiente septentrional de la cordillera cantábrica", en Las "villae" tardorromanas en el Occidente del Imperio: arquitectura y función: IV Coloquio Internacional de Arqueología en Gijón. 2008.

GANSHOF, FrançOIS L. "Le statut personnel du colon au Bas-Empire: Observations en marge d'une théorie nouvelle", L'antiquité classique, 1945, vol. 14.

García y Bellido, Antonio. La Legio VII Gemina Pia Felix y los orígenes de la ciudad de León. 1950.

García y Bellido, Antonio. "Cohors I Gallica Equitata Civium Romanorum", Conimriga, 1959, vol. 1. 
García y Bellido, Antonio. "El "Exercitvs Hispanicvs" desde Augusto a Vespasiano", Archivo Español de Arqueología, 1961, vol. 34.

GiBbOn, EDWARD. The Decline and Fall of the Roman Empire, Chicago, 1932.

Gil, EnRiQue MelChor. "Construcciones cívicas y evergetismo en Hispania romana", Espacio Tiempo y Forma. Serie II, Historia Antigua, 1993, n. ${ }^{\circ} 6$.

Gil, EnRIQUe MELCHOR. "Consideraciones acerca del origen, motivación y evolución de las conductas evergéticas en Hispania romana", Studia bistorica. Historia antigua, 1994, n. ${ }^{\circ} 12$.

Grenier, Albert. Habitations gauloises et villas latines dans la cit? des M? diomatrices. Рипол Классик, 1906.

GORGES, JEAN-GÉRARD. Les villas bispano-romaines: inventaire et problématique archéologiques. 1979

Gorges, JEAn-GÉrARd y CHAVArrí ARnAu, AleXANDra. El final de las villae en Hispania (siglos IV-VII d.C.) (Bibliotheque de l'Antiquité tardive, 7), Association pour l'Antiquité tardive y Brepols, Turnhout, 2007.

GORGES, JEAN-GÉRARD. "L'architecture des villae romaines tardives: La création et le développement du modèle tétrarchique", en Las "villae" tardorromanas en el Occidente del Imperio: arquitectura y función: iv Coloquio Internacional de Arqueología en Gijón. 2008.

Grut Esparraguera, José María, Ramos, Isabel SÁnCHEZ. "Topografía cristiana en Hispania durante los siglos V y VI", Zona arqueológica, 2008, n. ${ }^{\circ} 11$.

Gurt Esparraguera, José María; Ramos, Isabel SÁnChez. "La ciudad cristiana en el Mediterráneo occidental. La comprensión del mundo urbano tardío desde una perspectiva material", Mainake, 2009, n. 31.

Gurt EsParraguera, José María. "Transformaciones en el tejido de las ciudades hispanas durante la Antigüedad tardía: dinámicas urbanas", Zepbyrus: Revista de prebistoria y arqueología, 2000, n. ${ }^{\circ} 53$.

Gurt Esparraguera, José María y Josep M. Palet Martínez. "Structuration du territoire dans le nord-est de l'Hispanie pendant l'Antiquité tardive: transformation du paysage et dynamique du peuplement", en Les campagnes de la Gaule à la fin de l'Antiquité. Habitat et peuplement aux IVe et Ve siècles. Colloque AGER IV. Editions APDCA, Antibes. 2001. pp. 303-329.

Gurt Esparraguera, José María y Macías Solé, Josep María. "La ciudad y el territorium de Tarraco: el mundo funerario", en Espacios y usos funerarios en el Occidente 
romano: Actas del Congreso Internacional celebrado en la Facultad de Filosofía y Letras de la Universidad de Córdoba (5-9 junio, 2001), Seminario de Arqueología, 2002.

GutiérRez GonZÁLEZ, José Avelino. "Las villae y la génesis del poblamiento medieval", Las "villae" tardorromanas en el Occidente del Imperio: Arquitectura y función: IV Coloquio Internacional de Arqueología en Gijón, 2008.

Heather, Peter. "Resistiendo al enemigo: Defensa de las fronterasy el bajo Imperio romano", en El arte de la guerra en el mundo antiguo: de las guerras persas a la caída de Roma. Crítica, 2012.

ISAAC, BENJAMIN. "The meaning of the terms limes and limitanei", Journal of Roman Studies, 1988, vol. 78 .

Isla FreZ, AmANCiO. "Villa, villula, castellum. Problemas de terminología rural en época visigoda", Arqueología y territorio medieval, 2014, vol. 8.

Jones, ARnOld Hugh MarTin. The later Roman Empire, 284-602: A social economic and administrative survey, Taylor \& Francis, 1986.

JONES, ARnOld Hugh MARTIN. "Capitatio and Iugatio", en JRS 47, 1-2, 1957.

JONES, RiCHARD F. "The Roman military occupation of north-west Spain", Journal of Roman Studies, 1976, vol. 66.

Jordá CerdÁ, FrancisCo. Las Murias de Beloño (Cenero-Gijón): una "villa" romana en Asturias. Servicio de Investigaciones Arqueológicas, 1957.

KeAY, SimOn. "Recent archaeological work in Roman Iberia (1990-2002)", Journal of Roman Studies, 2003, vol. 93.

KulikOwSKI, Michael. "The "Notitia Dignitatum" as a Historical Source", Historia: Zeitschrift für Alte Geschichte, 2000, n. ${ }^{\circ}$ H. 3, p. 358-377.

LE BOHEC, YANN. El Ejército romano, trad. esp., Barcelona, 2006.

LÓPEZ Quiroga, Jorge y MArtín, F. Germán RodríGuez. "El "final" de las "villae" en Hispania. I. La transformación de las Pars urbana de las villae durante la Antigüedad Tardía", Portugalia, 2000, n. ${ }^{\circ} 21$.

Macías Sole, Josep María. "Tarraco en la Antigüedad Tardía: un proceso simultáneo de transformación urbana e ideológica", Los orígenes del Cristianismo en Valencia y su entorno, 2000.

Macias Solé, Josep María. "Los "suburbia" en el Mediterráneo de la Hispania Citerior, o los termómetros de la salud del Imperio", en El paysage périurbain en Médite- 
rranée occidentale pendant la Protobistoire et l'Antiquité: actes du colloque international, Institut Catalan d'A. Institut Català d'Arqueologia Clàssica, 2012.

MacMullen, Ramsay. Soldier and Civilian in the Later Roman Empire: Ramsay MacMullen. Mass., Harvard University Press, 1967.

MARTíneZ MELÓn, JOSÉ IGNACIO. "El vocabulario de los asentamientos rurales (siglos I-IX d. C.): evolución de la terminología", en Villas tardoantiguas en el Mediterráneo Occidental. Consejo Superior de Investigaciones Científicas, 2006.

Martindale, John Robert; Мартиндейл, Джон Роберт. The Prosopography of the Later Roman Empire, volume II AD 395-527, 1980.

Menendez Argüin, Adolfo Raúl. El ejército romano en campaña: de Septimio Severo a Diocleciano (193-305 DC). Universidad de Sevilla, 2011.

Neira Faleiro, CONCEPCiÓn. La "Notitia Dignitatum": nueva edición crítica y comentario bistórico. Universidad Complutense de Madrid, 2003.

Palanca, Adela Cepas. Crisis y continuidad en la Hispania del siglo III. Consejo Superior de Investigaciones Científicas, 1997.

Pérez losada, Fermín. "Hacia una definición de los asentamientos rurales en la Gallaecia: poblados (vici) y casas de campo (villae)", en Los finisterres atlánticos en la Antigüedad: época prerromana y romana (Coloquio internacional): bomenaje a Manuel Fernández Miranda. Electa España, 1996.

Pérez losada, Fermín; Fernández, Adolfo Fernández y Covela, Santiago VIEITO. "Toralla y las villas marítimas de la Gallaecia atlántica. Emplazamiento, arquitectura y función", en Las "villae" tardorromanas en el Occidente del Imperio: Arquitectura y función: IV Coloquio Internacional de Arqueología en Gijón. 2008.

Perea Yébenes, Sabino. "Documentación del exercitus bispanicus: soldados y oficiales de alas y cohortes con etnónimo hispano en inscripciones y papiros griegos. Prosopografía", Aquila Legionis, 7, 2006,

Pereira Menaut, Gerardo. "Los castella y las comunidades de Gallaecia", Zephyrus: Revista de prebistoria y arqueología, 1982, n. ${ }^{\circ} 34$.

PAlol, Pedro. La villa romana de La Olmeda de Pedrosa de la Vega (Palencia), 1996.

Prieto Brogiolo, Gian; Chavarría Arnau, Alexandra. El final de las villas y las transformaciones del territorio rural en Occidente (siglos V-VIII). 2008.

LOSADA, FERmín PÉREZ. "Entre a cidade ea aldea: estudio arqueohistórico dos "aglomerados secundarios" romanos en Galicia". Brigantium: Boletín do Museu Arqueolóxico e Histórico da Coruña, 2002, n. ${ }^{\circ} 13$. 
Mar R. y Perich A. "Casa y ciudad en la Hispania tardoantigua. La evolución de los modelos tipológicos", en La villa restaurata e i nuovi studi sull'edilizia residenziale tardoantica, Atti del Convegno del CISEM, Bari, 2014.

Revuelta Carbajo, Raúl. "La ordenación del territorio en Hispania durante la Antigüedad Tardía", Estudio y selección de textos, Madrid, 1997.

Ribera LaCOmba, AlberT. "La topografía de los cementerios romanos de "Valentia"'", Saitabi, 1996.

Ribera, Albert; Roselló, Miquel. "Los orígenes del Cristianismo en Valencia y su entorno", Grandes Temas Arqueológicos, 2000, vol. 2.

Ruiz Bueno, MANuel Dionisio. "La ruptura funeraria del pomerium desde su nacimiento y hasta su desaparición. Enterramientos in urbe. Onoba", Revista de Arqueología y Antigüedad, 2013, n. ${ }^{\circ} 1$.

RuIZ, E., et al. "Transformaciones urbanísticas de Carthago Nova (siglos III-XIII)", en IV Congreso de Arqueología Medieval Española, 1993.

Sanz Serrano, Rosa. "Aproximación al estudio de los ejércitos privados en Hispania durante la Antigüedad tardía", Gerión, 1986, n. ${ }^{\circ} 4$.

Sanz Serrano, Rosa. "Aristocracias paganas en Hispania Tardía (s. V-VII)", Gerión. Revista de Historia Antigua, 2007.

SÁnChez PARdo, José Carlos. "Organización eclesiástica y social en la Galicia tardoantigua. Una perspectiva geográfico-arqueológica del Parroquial Suevo", Hispania Sacra, 2014, vol. 66, n. ${ }^{\circ} 134$.

SÁNCHEZ RAMOS, ISABEL. Topografía cristiana de las ciudades bispanas durante la Antigüedad tardía, BAR International Series, Oxford, 2014.

Santos Yanguas, Narciso Vicente. "Las villas romanas en Asturias", Memorias de bistoria antigua, 1984, n. ${ }^{\circ} 6$.

SAntos Yanguas, NARCiso ViCEnTE. "La cohorte I de caballería de los astures en el ejército imperial romano", en Studia Zamorensia, 2. etapa, vol. VIII, 2008

SAyas AbengocheA, JuAn José. "La administración en el Bajo Imperio", en AA.VV., Historia de España Antigua, 2, Hispania Romana, 3. ${ }^{\text {ed }}$. Madrid, 1988.

Sayas Abengochea, Juan José. Historia antigua de la Peninsula Ibérica, Madrid, 2003.

SIRKS, ADRIAN JOHAN BOUDEWIJN. "The Colonate in Justinian's Reign", en JRS 98, 2008. 
SACCOCCIO, A. "Il modello delle azioni popolari romane tra diritti diffusi e 'class actions'", en 'Actio in rem' e 'actio in personam'. In ricordo di Mario Talamanca, L. GAROFALO (ed.), vol. I, Padua, 2011.

TEJA, RAMÓN. "Honestiores y humiliores en el Bajo Imperio: hacia la configuraciónen clases sociales de una división jurídica", Memorias de bistoria antigua, 1977, n. ${ }^{\circ} 1$.

TOYnBeE, Jocelyn M.C. Death and burial in the Roman world, JHu Press, 1996.

Ubric Rabaneda, PURIFICACiÓn. "Hacia la superación de los prejuicios: la integración del bárbaro en la vida cotidiana del Imperio romano tardío", en Formas de integración en el mundo romano: Actas del VI Coloquio de la Asociación Interdisiciplinar de Estudios Romanos, Signifer Libros, 2009.

VAn BerChem, Denis. L'Armée de Dioclétien et la réforme constantinienne, París, 1952.

Ventura, Francisco SALVAdor. "La función religiosa de las ciudades meridionales de la Hispania Tardoantigua", Florentia Iliberritana, 1996, n. ${ }^{\circ} 7$.

VIZCAÍNO SÁNCHEZ, JAIME. "Transformaciones del urbanismo tardoantiguo en cartagena. el caso de los vertederos", en Anales de Prebistoria y Arqueología, 1999.

WARD-PERKINS, JOHN BRYAN. "From Republic to Empire: reflections on the early provincial architecture of the Roman West", Journal of Roman Studies, 1970, vol. 60.

Wells, Benjamin W. "Taxation and Bureaucracy in the Declining Empire", The Sewanee Review, 1922, vol. 30.

WhitTAKeR, Dick. "Landlords and warlords in the later Roman Empire", War and Society in the Roman World, 1993, n. ${ }^{\circ} 5$. 